\section{A BIZTOSÍTÓK ÉRTÉKESÍTÉSI STRATÉGIÁJÁNAK TÁMOGATÁSA ÚJ TECHNOLÓGIÁKKAL}

Fülöp Attila*

Kulcsszavak: biztosításértékesítés, digitalizáció, jutalékrendszer, gamification, értékesítéstámogatás

JEL: G22

DOI: $10.18530 /$ BK.2015.3.48

http://dx.doi.org/1018530/BK.2015.3.48

\section{ÖSSZEFOGLALÓ}

A tanulmány elsődleges célja annak bemutatása, hogy a többcsatornás értékesítési modell terjedése, az egyes értékesítési csatornáknak a digitalizációval kapcsolatos változása, illetve a digitális világgal szemben különösen a fiatalabb generációkban növekvő - a biztosítási viszony forrásaként szolgáló - bizalom hogyan értékeli át a biztosítási informatika feladatát?

A cikk elemzi az értékesítési csatornák európai adatait, bemutatja a kapcsolódó szabályozási kihívásokat, ahol a jogalkotó elsődleges célja, hogy elősegítse az értékesítés misselling-motivációktól való tisztulását, ügyfélbarátabbá válását. Ennek kapcsán a jutalékrendszernek elsősorban támogató feladata van, illetve felértékelődnek a modellezést, tervezést erősítő képességek.

A biztosítók informatikai felelősei - ezen belül pedig a jutalékrendszerekéi - kettős kihívás előtt állnak. Egyrészt hagyományos módon támogatniuk kell a biztosítási folyamatokat, másrészt pedig mérlegelniük kell a viszonyulást ahhoz a kijelentéshez, hogy a digitalizácó térnyerésével az informatika már nemcsak „megoldás-szállító”, hanem „az üzlet része”.

\section{Bevezetés}

A XXI. század elején történetének egyik legnagyobb kihívása elött áll a biztosítási piac. A kihívások részben technológiai, részben - ettől nem függetlenül - társadalmi jellegűek. Az informatikai technológiák fejlődése folyamatosan új lehetőségeket teremt a mindennapi életben, a munkahelyeken. Nincs ez másként a biztositóvállalatok belső működésében, az értékesítési területen és az ügyfelek elérésének módjában sem. A szereplőknek arra kell készülniük, hogy a jelenlegi struktúrák megváltoznak, gyorsul a piac reakcióideje, lépéshátrányba kerül, aki nem fejleszt. A tradicionális értékesítési formák nem tünnek el, de a hangsúlyok eltolódnak az online lehetőségek személyes igénybevételének irányába [28].
A továbbiakban érdemes megkülönböztetni az élet- és a nem-életbiztosításokat:

Az életbiztosítások terén a bizalom mindig meghatározó szerepet játszott - így feltehetően a jövőben sem lehet nélkülözni a személyes találkozókkal támogatottértékesítést. A 90-es évek elején azonban, az internetes „csodavárás”, a direktbiztosítók születésének időszakában még az angol nyelvű sajtóban is komoly cikkek jelentek meg arról, hogy ki milyen életbiztosítást fog vásárolni az interneten keresztül [26]. Bár születtek életbiztosítást is sikeresen értékesítő direktbiztosítók, az optimizmust mára inkább a szkepszis váltotta fel - a másik személybe vetett bizalom továbbra is meghatározó tényező maradt. Úgy tűnik, hogy a kezdeti fellángolást követően a közvetítők az internet és a közösségi média szerepét mára inkább a kapcsolatépitésben találták meg [7], bár a kérdés nem jutott nyugvópontra.

A sikeres direktbiztosítókra az egyszerüség a jellemző - ez egyaránt jelenti a termék céliának egyértelműségét (pl. kockázati védelem vagy nyugdij) és a biztosításkötési folyamat rövidségét és sallangmentességét is (pl. orvosi vizsgálat hiánya).

Mindez bizonyos szempontból igaz az életbiztosítások banki értékesítésére is. Nyilvánvaló, hogy azok a termékek értékesíthetők jól, ahol az értékesítő is hiteles - az életbiztosításhoz szükséges pénzügyi kompetencia feltételezhető a banki dolgozókról is. Másfelől azonban az is igaz, hogy a banki dolgozók munkaidejének csak elenyésző töredéke szól az életbiztosítások értékesítéséről, illetve az ehhez szükséges oktatásokon való részvételről - emiatt fontos, hogy a banki értékesítésre szánt termékek jelentős mértékben építsenek a banki adottságokra, az addicionális tanulás igénye csak a szükséges mértékben álljon fenn -, ez szintén az egyszerüsités irányába ható követelmény.

A digitalizáció szerepe és lehetőségei a banki értékesítést illetően inkább a folyamatszervezésben mutatkoznak meg. Miután a banki dolgozók általában személyi számítógépet használnak, sok bankbiztositó készít számukra integrált funkcionalitású, egyszerű használatú front-rendszereket. Az ilyen front-end rendszerek egyik legjelentősebb következménye, hogy lehetővé teszi az input adatok ellenőrzését, ezzel lehetővé válik a belső, adminisztratív munkafolyamatok automatizálása, végső soron pedig az egységköltségek alacsony szintre szorítása.

Hasonló hatás a személyes értékesítést is érte - a 90-es évek közepétől előtérbe került a korábban nem létező laptopos értékesítés, díjkalkulációs és prezentációs segítséget nyuujtva az értékesitők számára, egyben megnyitva az adminisztráció felé az adattovábbítás lehetőségét.

A technológiai fejlődés tehát inkább közvetett módon, az egyes munkafolyamatokra gyakorolt hatásain keresztül befolyásolta az életbiztosítási ügyfelek és a szolgáltatók kapcsolatát, az életbiztosítási termékek tanácsadás-igényessége következtében kisebb volt az értékesítésre, az értékesítési csatornákra gyakorolt hatás - ahogy ezt a későbbiekben látni fogjuk.

A nem-életbiztosításoknál a biztosításkötés kapcsán elvárt hitelesség terén az elektronizáció és a fokozódó internethasználat új lehetőségeket is teremtett: tudható, hogy azoknál a biztosításoknál, ahol a szolgáltatás sztenderd vagy független a szerződőtől, egyszerübb a döntés - az olcsóbb a jobb. Ennek ékes példáját tapasztalhattuk Magyarországon is például a kötelező gépjármű-felelősségbiztosításnál, ahol éveken keresztül az ár alapján döntő ügyfelek százezrei váltottak biztosítót az internetes alkuszcégeknél, amelyek minden szolgáltató díjajánlatát meg- 
mutatták, könnyen kiválaszthatóvá téve ezzel a legolcsóbbat. Mindez nem jöhetett volna létre a díjkalkulációk elektromos úton való gyors elvégezhetősége, összehasonlíthatósága, illetve az internet kínálta széles körü elérhetőség nélkül ${ }^{1}$ - a technológia fejlödése és a megváltozó szokások átrendezték az értékesítési csatornákat.

Hasonló következtetésre jutott a CEA is az értékesítési csatornákat elemző kiadványában [3]: eszerint „a vásárlások növekvő volatilitása és az ügyfelek elérésének igénye a többcsatornás (multichannel) értékesítési stratégiákat helyezi előtérbe, ami egyszerre jelenti az új értékesítési csatornák (bevásárlóközpontok, internet, call centerek) fejlesztését és a hagyományos csatornák - ügynökök és alkuszok - megtartását. Ez a stratégia erodálja a domináns csatornák részarányát a tőlük származó díjbevétel szintjének többé-kevésbé stabilan maradása mellett.

\section{A csatornák számának növekedésével nőnek a}

\section{termékfejlesztéssel szemben támasztott követelmények.}

Miután az ügyfelek nem szívesen változtatnak meglevő biztosítási szerződéseiken, inkább az összdíj növekményéről (ti. új szerződésekrőll) beszélhetünk, ez a többlet pedig új hálózatok fejlödésével állt elő. Ez volt a helyzet az elmúlt 10 évben a bankbiztositás esetében, ahol a fejlődés leginkább az életbiztositások erös növekedésével történt."

Az értékesítési csatornák éleződő versenye nem hagyja érintetlenül a termékfejlesztést sem; a csatornák számának növekedésével nőnek a termékfejlesztéssel szemben támasztott követelmények, mind a fejlesztések gyorsaságát, mind pedig a termék hátterének működését illetően. Az egyes értékesítési csatornák oldaláról ez utóbbi általában az ügyfélpanaszok elkerülését és az - adott esetben az értékesítési csatornára szabott - értékesítésösztönzési rendszer működőképességének „megélhetőségét” jelenti. Ehhez pedig az szüikséges, hogy olyan, költséghatékonyan üzemeltethetö, rugalmas informatikai rendszer szolgálja ki a termékfejlesztést, amely képes a gyorsan változó üzleti környezetre megfelelő válaszokat adni.

Az informatika sok irányból adhat segítséget a biztositási szektornak - a sokoldalú használat lehetőségét mutatják a magyar biztosítók 2015-ös informatikai céljai is [22].

\begin{tabular}{|c|c|c|c|}
\hline jelleg & reláció & az informatikai közelités alapja & fontosabb kulcsszavak \\
\hline "kint" & ügyfél- világ & $\begin{array}{c}\text { a biztosítás pozicionálási kérdés } \\
\text { az informatikai alapú } \\
\text { eszközökön }\end{array}$ & $\begin{array}{l}\text { közösségi média, érthetöóég, } \\
\text { érdekessé tétel, játékositás stb }\end{array}$ \\
\hline $\begin{array}{l}\text { "intermedier } \\
\text { közeg" }\end{array}$ & ügyfél - szolgáltató & $\begin{array}{l}\text { a front egységek (értékesítés, } \\
\text { kárrendezés stb.) támogatása }\end{array}$ & "kint" + "bent" + funkcionalitás \\
\hline "bent" & $\begin{array}{l}\text { szolgáltatói egység - } \\
\text { szolgáltatói egység }\end{array}$ & $\begin{array}{l}\text { hatékonyság, pontosság, } \\
\text { biztonság }\end{array}$ & $\begin{array}{c}\text { folyamattervezés, adatátvitel, } \\
\text { biztonság stb. }\end{array}$ \\
\hline
\end{tabular}

1. ábra: Az IT-szolgáltatások jellemzö felhasználási jellege a biztositóiparban (Forrás: saját csoportositás)
A kapcsolatok jellege szerint csoportosítva a lehetöségeket, az informatikai megoldások és támogatások jelentős része az alábbi rendszerbe jól beleilleszthető:

Különösen izgalmas és kihívásokkal teli az ,intermedier közeg” - itt egyaránt érvényesülnek a „Kint” és a „Bent” szempontjai, kiegészítve az adott területet jellemző funkcionalitás kihívásaival.

Az értékesítési/értékesítéstámogatási területet vizsgálva például fontos az ügynökök, brókerek megfelelol támogatása azáltal, hogy a biztositó gyorsan és átláthatóan pontos jutalékot kalkulál ki, illetve, ha új terméket vezet be, akkor azt egyszerüen és gyorsan teszi. Lényeges, hogy a közvetítő (ügynök vagy alkusz) is ügyfélként viselkedik abból a szempontból, hogy a biztosító szolgáltatását veszi igénybe.

Így itt is érvényesülnek a közösségi médiából beszivárgó elvárások, a szórakoztató, játékos környezet. Másfelől a közösségi médiában is fontos a hitelesség, itt nincs jelen a dedikált értékesítő; az adott biztosító megjelenése vagy valamilyen más hozzáadott értéke az, ami közel hozhatja az ügyfeleket a szolgáltatóhoz

\subsection{A tanulmány célja és módszertana}

Jelen tanulmány célja annak a bemutatása, hogy a többcsatornás értékesítés terjedése, az egyes értékesítési csatornák súlyának a digitalizációval történő változása, illetve a digitális világgal szemben különösen a fiatalabb generációkban növekvő - a biztosítási viszony forrásaként tételezhető - bizalom hogyan értékeli át a biztosítási informatika feladatát. Abból kiindulva, hogy a biztositási folyamatok támogatásának fontossága mellett a digitalizácó térnyerésével az informatika már nemcsak „megoldás-szállítóként”, hanem „az üzlet részeként” is számításba vétetik, a „fronthoz” viszonylag közeli jutalékrendszer példáján és a vele szemben támasztott kihívásokon keresztül vizsgáljuk meg az online tér terjedő használatával a biztosítók számára kínálkozó lehetőségeket.

A tanulmány során először az értékesítési csatornák kialakulására és fejlődésére vonatkozóan irányadó trendeket mutatjuk be, kitérve a szabályozás fontosabb tendenciáira is.

Ezt követően azt mérjük fel, hogy a közvetlen értékesítő-ügyfél kapcsolat, illetve a technológiai fejlődés, a 90-es évektől felgyorsult digitalizáció milyen követelményeketállít a jutalékrendszerek elé.

Végezetül igyekszünk feltérképezni azokat a lehetőségeket, amelyek a digitalizáció, az online világ terjedésével kihasználhatók a biztositók és az értékesités számára

\section{2. Áttekintés}

\subsection{A XXI. század elött}

A biztosítói szakma a kezdetektől papíralapú megoldásokkal dolgozott: megírták, illetve később nyomtatták a kötvényeket; papíron összesítették a bevételeket és a kiadásokat, ezeket lefüzték, iktatták, raktározták; papíron tervezték a társaság jövőjét, és papíron számolták az ügynökök jutalékát is. Így mülödtek a biztosítók az 1600-as évektől gyakorlatilag az 1970-es évekig, amikor új technológia lépett piacra: a számítógépek.

A számítógépek megjelenése és elterjedése után egyre több területen jelentek meg az elektronikus megoldások, amelyek megkönnyítették és felgyorsították a munkafolyamatokat. 
Első körben a könyvelés, az üzleti portfólió és az ügyféladatok digitalizálása történt meg - ezt ma már szinte minden társaságnál elektronikus módon intézik és tárolják. A 2000-es években megjelentek az online alapú szerződések is: ma már Magyarországon is mindennapos, hogy utasbiztosítást, illetve kötelező gépjármü-felelősségbiztosítást az interneten keresztül kötnek meg a vásárlók.

Az IT-szektor azonban ennél jóval többet is adhat a biztosítási piacnak.

\subsection{Nemzetközi trendek}

Napjaink kiindulópontja az a helyzet, hogy az új biztosítottak nagy része a negyven év alatti rétegből kerül ki, és ők intenzívebben használják az internetet, a közösségi média felületeket és mobilalkalmazásokat.

Ehhez a helyzethez a biztosítók is változatos megoldásokkal alkalmazkodnak.

Az egyszerúbbek között említhetők a díjak összehasonlítására, a szükséges nyugdíj-megtakarítás kiszámolására, lakásbiztosításoknál az ingóságok listájának folyamatos frissítésére vagy a biztosításhoz kötődő iratok és adatok tárolására készített applikációk. Létezik olyan alkalmazás is, amely az életbiztosításhoz kapcsolódó befektetési portfóliót figyeli, de olyan is akad, amely az egészségbiztosítás mellé a gyógyszerárakat és a kezelési költségeket monitorozza, sőt, alternatívákat is ajánl bizonyos esetekben.

Léteznek biztosítási jellegű közösségi alkalmazások is, amelyeken keresztül a biztosítottak, illetve a biztosításközvetítők tudják megosztani tapasztalataikat egyes cégekről és termékekről. ${ }^{2}$ A „könnyedebb” kategóriában olyan alkalmazások találhatók, amelyek a biztosítótársaság reklámjait gyüjtik össze és vetítik le a mobilkészüléken, vagy a speciálisan egy célcsoportnak ajánlott hasznos szolgáltatások (például motorosok számára készült alkalmazás, integrált útvonaltervezővel, benzinkutakkal, kórházakkal és egyéb, a motorozás szempontjából fontos információkkal). A „súlyosabb” kategóriában találhatók például a rating iparág képviselöi, amelyek a saját elemzési, szakmai tudásukon alapuló kijelentéseiket a biztosítottaknak az internet nyújtotta nyilvánosságot kihasználva juttatják el, sokszor a rating egyes elemeinél is speciális informatikai alkalmazásokat használva.

De vannak biztosításhoz kapcsolódó játékok is, mint például a Council for Disability Awareness [10] játéka, amelyben egy küzdőteremben különböző egészségügyi problémákkal kell harcolni, a ráktól a szülés közben fellépő komplikációig. Itt a játékos a fordulók között kérdés-válasz formájában kap ismereteket a problémákkal járó nehézségekről és a különleges élethelyzetekre vonatkozó biztosításokról.

A biztosítási ügynökök számára is készülnek mobilalkalmazások. Az AFLAC [11] a prezentációihoz készíttetett alkalmazást, amelyet tabletjeikre tölthetnek le az ügynökök, sőt maga a cég látta el táblagépekkel mintegy 150 New York-i kereskedőjét.

A biztosítótársaságok azonban nemcsak az online megjelenésekhez használják az informatikai fejlesztéseket. Folyamatos a szolgáltatók rendszereinek modernizációja, a folyamatoptimalizációk mentén létrejövő kompatibilitás, platform-egységesülés, illetve integráció a teljes adatvagyon, illetve annak kezelése vonatkozásában egyre meghatározóbb tényezők. Ebbe beletartozik a biztosítási portfóliók, az ügyféladatok, a termékspecifikáció és az értékesítői ösztönzőrendszer elektronikus kezelése is.

A trendbe az is beleillik, hogy a korábbi robusztus informatikai rendszereket szétszabdalják egyszerűbben kezelhető informatikai rendszerekké, amelyek rugalmasabban tudják kielégíteni az üzleti igényeket, illetve, ha erre nincsen lehetőség, akkor olyan előtétrendszereket alakítanak ki, amelyek biztosítják az elvárt rugalmasságot.

Ennek megfelelően a nagy biztosítótársaságok informatikai rendszereinek modernizálása Nyugat-Európában és az Egyesült Államokban a technológia fejlődésével folyamatossá vált, a szervesebb fejlődés következében pedig a szabályozás is naprakészebb.

Hazánkban a szabályozás ezzel szemben sokszor átvevő-követő jellegű; egyik legfrissebb eleme a közvetítői jutalékrendszer kereteinek változtatására irányul, a továbbiakban ezt a kérdést járjuk körül.

\section{Szabályozási és történeti háttér}

\subsection{A kihívás: felértékelődő fogyasztóvédelem}

A korábbi szabályozások nagy teret hagytak a piacnak, illetve a piaci önszabályozási mechanizmusnak - ezt első látásra indokolttá is tette, hogy a biztosítótársaságok száma a legtöbb országban magas, többé-kevésbé homogének a termékek, a verseny piaci modelljének feltételei így alapvetően biztosítottak. Emiatt az iparág szabályozóktól való autonómiája sokáig magas volt, „cserébe” egyfajta elöre gondolkodásért és önszabályozásért.

Így volt ez az első biztosításközvetítői irányelv (IMD1 - 2002/92 sz. EU direktíva) elfogadásának idején is. Az irányelv [18] leginkább a biztosításközvetítők kompetenciáját, képzési követelményeit, a felelösségi viszonyokat, illetve a közvetítői regisztrációt és annak transzparenciáját tekintette központi kérdésnek, a megoldások vonatkozásában pedig jelentős tagállami szabadság volt biztosított.

Másfelől az európai törvényhozásban megfigyelhető általános tendencia a fogyasztóvédelem megerősödése [12] is; könnyen belátható, hogy ez politikailag hálás, sok területen jól kommunikálható téma.

Így nem csoda, ha a második közvetítői irányelvben (IMD2/IDD) is felbukkan a fogyasztóvédelmi szempont (kötvénytulajdonosok védelmének erősítése), a piaci verseny erősítésének célja mellett [19].

\subsection{A közvetítői rendszerekröl}

Magyarországon legutóbb 2015. január 1-jei hatállyal szabályozták a biztosítási termékekhez kapcsolódó jutalékok kérdését.

A jutalékozás kérdésköre szempontjából meghatározó a közvetítői közeg minősége - az egyes országok eltérő biztosításközvetítési kultúrája meghatározta a jutalékozási szabályrendszert is. Például az alkuszok dominálta Angliában sok esetben nincs jutalékkifizetés, viszont a biztosítottak fizetnek a tanácsadásért a közvetítőnek. A kontinentális 
Európában viszont jellemzően a biztosítók fizetnek - az angolszász és a kontinentális gyakorlat közt nem is feltétlenül a mértékben van a legnagyobb eltérés, sokkal inkább a transzparenciában.

A biztosítók által fizetett jutalékok értékesítési csatorna szerint eltérőek - a saját értékesítési hálózatban dolgozók számára általában alacsonyabbak a jutalékkulcsok, mint az önálló iroda költségeit is viselö alkuszok számára. A bankokban elvileg akár alacsonyabb jutalékokat is lehetne fizetni, hiszen az infrastruktúra költségeit a banküzemnek természetes módon is ki kell gazdálkodnia, ám a bankok legtöbbször elég jó alkupozícióban vannak ahhoz, hogy magasabb jutalékokat tárgyaljanak ki maguknak. Az egyes bankokon belül ugyanakkor színes belső motivációs rendszerek működnek, amelynek a biztosítási jutalék is része.

A jutalékot a legfőbb motivációs eszköznek tekintve foglalkoznunk kell az aránytalansággal. Az aránytalanság nem csak az egyes biztosítók, illetve termékek között értelmezhető (itt az aránytalanságok oka - indokoltan - a társaságok eltérő sikeressége, vagy az egyes termékek iránti eltérő kereslet is lehet), az indokolatlan aránytalanságot leginkább az elöleg jellegü jutalékok mértéke jelentette, illetve az, hogy ezt az ügyfelekkel nem ismertették. Gyakran például a kötéskor kifizetésre került az első éves díjnak akár 150-180 százaléka, ami nemhogy a befizetett díjjal nem áll arányban, de az értékesítése is gyakran csak a magas hozam (bizonytalan) reményére alapozott, aránytalan elvárásokat keltve ezzel az ügyfelekben (misseling / nem a valódi vásárlói igényekre épített motiváció).

2015. január 1-jétől lépett hatályba az a módosítás, amelyet a szakzsargon „csepegtetett jutalékkifizetés"-nek hív. Ez azt jelenti, hogy megtakarítás jellegü életbiztosítások esetében jutalékként föszabály szerint legfeljebb csak annyi pénz fizethető ki, amennyi díj befolyt a biztosítóhoz.

A törvény hatályba lépése előtt az egyes értékesítési csatornákat tehát eltérő rendszerben ösztönözték. Az MLM-hálózatoknál rendszeresen alkalmaztak olyan értékesítési módszereket, amelyek segítségével sok ügyfelet sikerült egy adott biztosítóhoz szerződtetni. Elfogadott módszer volt például, hogy az MLM-es üzletkötőjelöltnek elöször saját magára kellett életbiztosítást kötnie, azzal a megfontolással, hogy a folytatólagos biztosítási díjak fedezetét majd az eladásaiból származó jutalék kitermeli [23], [24].

Ezzel a módszerrel egyszerre lehetett növelni az MLM létszámát és jutalékbevételét, illetve a velük kapcsolatban álló biztosítók ügyfélkörét. Az így kötött kötvények azonban sok esetben (például üzletkötői távozás esetén) továbbfizetés hiányában végül megszűntek - mindez nem is csoda, hiszen eredendően sem volt meg az ügyféligény a biztosításra.

Ez a rendszer egyes MLM-értékesítő vállalatok hegemóniájához vezetett, további negatív hozadékként pedig a biztosítási piacba vetett bizalom is megingott.

Az új szabályozás a nagy vonzerőt jelentő előfinanszírozás, a „könnyü pénz” megszüntetésével alkalmas arra, hogy a bizalomrombolás alábbhagyjon, és a piac karaktere is egészségesebb, az ügyfelek valós érdekeit jobban figyelembe vevő irányba változzék.

\subsection{Az értékesítési csatornák átértékelődése}

A Swiss Re szakmai folyóirata egyik cikkében az életbiztosítások értékesítését illetően az alábbi grafikont közli [25]:

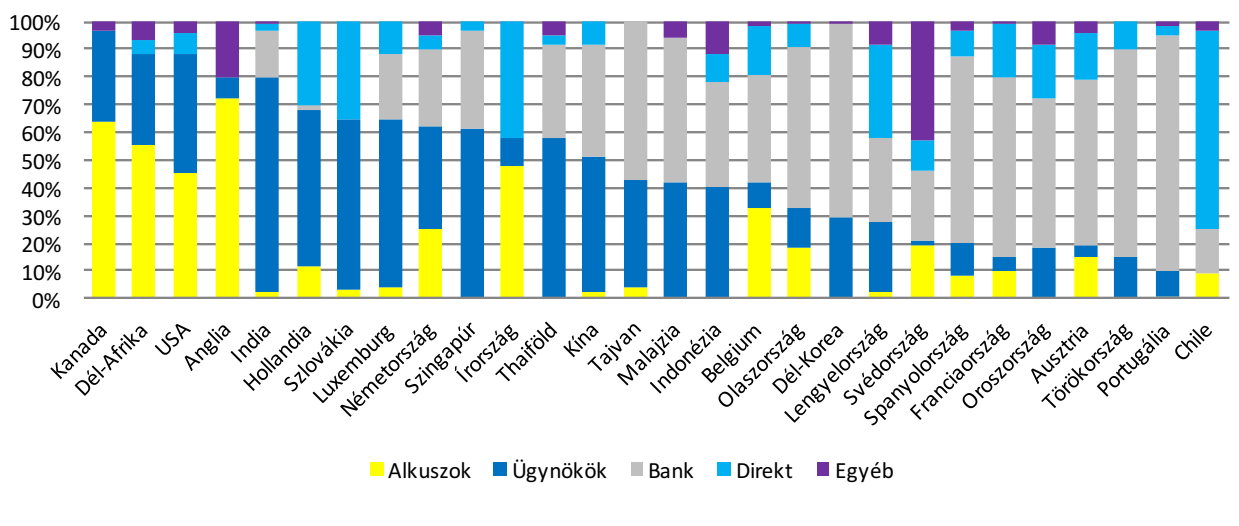

2. ábra: Életbiztositások értékesitése csatornák szerint (Forrás: Swiss Re gyüjtés [25])

Látható, hogy az életbiztosítás esetében az egyes értékesítési csatornák regionális eltérései jelentősek. Néhány - főként angolszász - országban az ügynöki és alkuszi értékesítés dominál, másutt a bankoknak van nagyobb szerepük, illetve eltérő súlyúak a direkt csatornák is. A továbbiakban szükítjük a geográfiai vizsgálódás körét, az USA illetve Európa néhány országában tekintjük át az egyes értékesítési csatornák helyzetét, illetve az arányok változását:

Az életbiztosítás esetében az egyes értékesítési csatornák regionális eltérései jelentősek.

3.3.1. USA

Az III. (Insurance Information Institute) 2014-es elemzése [9] az alábbiakat állapítja meg az USA biztosításértékesítési piacáról:

- Nagy különbségek vannak a biztosítótársaságokkal jól azonosítható értékesítési csatornák, illetve ennek válfajai (kizá rólagos ügynökök, saját honlapos értékesítés, illetve direkt értékesítés), valamint a több biztosítótársasághoz is kötődő csatornák (független ügynökök, alkuszok) között.

- A biztosítókhoz jól köthető csatornák uralják a gépjármű- és a lakásbiztosítási piacot (a 2013. évi díjbevétel 73, illetve 69\%-a származik tölük).

- A független csatornák domináliák a vállalati piacot, a díjbevétel 67\%-ával (2013).

- Mintegy 3,1 millió autóbiztosítást online módon értékesítettek 2012-ben.

A történet helyes megértése érdekében fontos tudni, hogy korábban az USA-ban 
is a kizárólagos ügynöki státusz (exkluzív képviselő stb.) volt a jellemző, később egyes ügynökségek akár több biztosító számára is értékesítettek (független ügynökök), ezt követően azután - föként a városokban - egyes független ügynökségek alkuszok lettek, gyakran kockázatelbírálási funkciókat is átvéve a biztosítóktól. A jogállásbeli különbség - a magyarországihoz hasonlóan - ott is abban áll, hogy az ügynök a szolgáltatót képviseli, míg az alkusz az ügyfelet.

A személyes értékesítésnek különösen az életbiztosításnál nagy a jelentősége - 2013-ban az új üzletek 49\%-a kötődik a független ügynökökhöz, míg 41\%-a a biztosítók exkluzív ügynökeihez.

A fentieket két tényező egészíti ki, a technológiai fejlődés és a biztositásértékesítési tevékenység kihelyezése (outlet)

- technológiai fejlődés: Ez a potenciális vásárlókkal való kapcsolatba lépés lehetőségeit szélesíti ki a direkt marketing változatos eszközeivel (levél, telefon, e-mail, internet stb.) Ennek kapcsán egyes termékek esetében eltérő módon kell kezelnünk az internetet: Míg 2012-ben az autóbiztosítást kötők mintegy 67\%-a vette ténylegesen is online módon a biztosítását, addig az életbiztosításnál inkább a vásárlást megelőző tájékozódásé a fő szerep - egy felmérés szerint a megkérdezettek 83\%-a használná elözetes informálódásra a netet, ha erre lehetősége volna.

- a tevékenység kihelyezése (outlet) - ide tartozik a banki, munkahelyi, civil közösségekben, áruházakban, autókereskedőknél stb. történő biztosításértékesítés - tulajdonképpen az egyes tevékenységek fogyasztói, gyakorlói, igénybe vevői körén való keresztértékesítésként vagy kapcsolódó, együttes értékesítésként definiálható.

\section{Ezek közül érdemes néhányat közelebbröl is szemügyre venni:}

Munkahelyi értékesítés: A munkahelyi (worksite) értékesítés az USA-ban leginkább az élet- és betegségbiztosításhoz kötődik, azon belül viszont meglehetősen kiegyensúlyozott az egyes kockázatok aránya, az értékesítési csatorna pedig inkább növekvő tendenciát mutat $(2013 / 12+4,3 \%)$

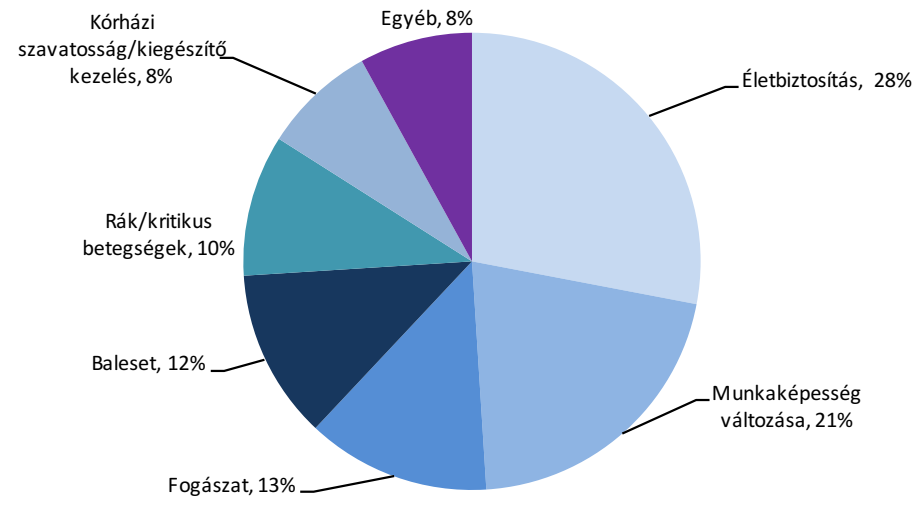

3. ábra: Munkahelyen kötött élet-és egészségbiztositások megoszlása (Forrás: 2013 USA [9])
Banki értékesítés: Ez az USA-ban is inkább az életbiztositásról szól

Közösségekben építkezés: ennek az USA-ban jelentős hagyományai vannak. Az első biztosítótársaság az angol Királyi Charta alá szerveződő Friendly Society keretei között jött létre, 1736-ban ennek a tagjai hoztak össze egy pénzügyi alapot tűz elleni védelemre. A társaság biztosítóként mindössze 6 évig működött, egy jelentős charlestoni tüzvész a társaságnak is véget vetett.

A közösségben építkezés kezdeti formáját meghaladva 1752-ben Benjamin Franklinnak sikerült elöször sikeresen a vásárlók felé is nyitott biztosítót létrehoznia. Philadelphiában az Union Fire Company elöször zárt társaságként indult, a tagok azonban később megszavazták a nyílt tagságot, dífizetés vállalása mellett.

Ezt követően több hasonló társaság is keletkezett, a népesség növekedésével, illetve a Nyugat meghódításával kiépültek az ügynökökre alapozott értékesitési hálózatok is.

Az első ismerten direkt marketing eszközöket is alkalmazó társaság az 1810-es alapítású Hartford volt, amely a levelezést, illetve a postahivatalokat használta terjeszkedésre azokon a területeken, ahol nem voltak ügynökei.

A XIX. század vége és a XX. század meghozta az automobilokat és vele a gépjármü-felelősségbiztosítást. Napjainkban inkább az jellemző, hogy az egyéni ügyfeleket az ügynökségek, míg a vállalati, kereskedelmi ügyfeleket az alkuszcégek szolgáljákki - ahogy ez egyébként többé-kevésbé Magyarországon is igaz.

Az idők során változtak az értékesítési csatornák súlypontjai is - az új, növekvő társaságok számára kézenfekvő volt a terjeszkedés a hatalmas területű országban a meglévő független ügynökségekre alapozva.

A közösségek kockázatainak megosztása a XX. század elején új fejlődésnek indult. Ezáltalában farmer-egyesületek létrejöttét jelentette - ekkor még a népesség negyede farmokon élt. Ezekből az egyesületekből esetenként ma is létező, nagy biztosítók lettek (State Farm, Nationwide, American Family and Farmers.). Ehhez némiképp hasonló utat járt be a hadsereg biztositóegyesülete is (United States Army Insurance Association, ma USAA).

Aziparosodó társadalmak szakmai szerveződései - ide érve az állami alkalmazottakat is - a XX. század első felében jelentős aktivitást mutattak. Például a GEICO [13], a mai amerikai piac egyik legnagyobb nyitott autóbiztosítója is úgy alakult 1936-ban, mint a kormányzati alkalmazottak számára biztosításokat nyúitó vállalat.

Ahogy egyre több társaság kezdett el többcsatornás értékesítést alkalmazni, úgy vált egyre fontosabbá a márka: az 1925-ben alakult, napjainkra a lakossági biztosítási piac egyik vezető szolgáltatójává vált Allstate [14] a 70-es évekre ennek segítségével tudott egyre több, korábban egyes ügynököt sikeresen magához vonzani.

A fentiek azt mutatják, hogy a biztosítás az USA-ban kezdetektől inkább személyekhez kötődő üzlet, amelyet a márka, az intézményi bizalom megerősít. Talán ennek is köszönhető, hogy a banki értékesítés kevésbé vált sikeressé, mint Európában.

A kezdeti infokommunikációs eszközök (távíró, telefon) használata is praktikusan szerveződött - leginkább a kockázatok jegyzésével, illetve a károk rendezésével kapcsolatos információtovábbítás igényét elégítették ki, segítve a biztositási ügynököket és alkuszokat tevékenységeik végrehajtásában. 
A 90-es évektől, az internet megjelenésétől újra változott a világ: az ügyfeleknek nyújtott szolgáltatások támogatása mellett a biztosítók online kötvényekben kezdtek el gondolkodni. A közvetítői piacra gyakorolt hatás kettős jellegü:

- Általánosan a közvetítők, függő és független ügynökök, ügynökségek számára is adott az a lehetőség (és egyben feladat), hogy az internet segítségével tegyék magukat vonzóvá és elérhetővé, illetve hogy használják a technikát az eddigi célokra, az ügyfelekkel történő információáramlás elősegítésére.

- A független ügynökök, ügynökségek, illetve az alkuszok számára ezt meghaladó lehetőségek mutatkoznak az összehasonlítással - ez leginkább a jól sztenderdizálható termékekre, az autóbiztosításokra és a kockázati (term life) életbiztosításokra igaz.

A fentieken túl azonban az is kijelenthető, hogy a gyorsuló technológiai változásoknak az életmódváltozásokon keresztuil vannakhatásai az emberi természetre is. Közkeletűnek tekinthető az 1900as évektől az alábbi generációs tagolás [15] (zárójelben néhány, a generációt jellemző kulcsfogalom): - 1920 és 1930 között születettek a Veteránok (a második világháborúból hazatértek - kulcsfogalmak: újjáépítés, urbanizáció, kemény munka)

- 1946 és 1964 között született embereké a Babyboom korszak (technológiai forradalom, kemény munka, jólét, emberi jogok)

- az 1965 és 1980 között születettek: X generáció (számítógép, a változás kontinuitása, pályakezdetkor jó lehetőségek, az elutasítással idősebb életkorban történő szembesülések)

- az 1980 és 1995 között születettek: Y generáció (internet, mobiltelefon, késői munkába lépés, fogyasztói szemlélet túlsúlya)

- 1995 után születettek: Z nemzedék (digitális technológiák, minden korábbinál erősebb médiafüggőség, a globalizáció növekvő természetessége)

Mindez jól mutatja a ciklusok rövidülését, és emellett azt is, hogy a kommunikáció, az információáramlás terepe egyre inkább a számítógép és a digitális média - egy olyan világ, amely az új fogyasztókat illetően inkább generációs alapon bővüil, a használt, népszerű eszközök, alkalmazások gyorsan avulnak, ahol a használat aktuális szabályainak elsajátítása korántsem magától értetődő, így vannak lemaradók is. ${ }^{3}$

A fentiek fényében az sem meglepő, hogy a digitális világ szabályainak használatát jól ismerő szolgáltatók igyekeznek tágítani a tevékenységi kereteiket, így például a Google is megnyitotta internetes platformját biztosításidíj-összehasonlító szolgáltatás formájában is, egyelőre csak a gépjármü-biztosítások vonatkozásában [16].

\subsubsection{Európa}

Európában az értékesítési csatornák súlyának mérésére nincsenek megbízható, bevált elemzések. Rendelkezésünkre állnak azonban az európai biztosítószövetség, a CEA által különböző időpontokban készült pillanatfelvételek. Itt is nehezíti azonban a helyzetet, hogy 2006-ig az értékesítési csatornák számbavétele alapvetően létszámalapon történt [2], 2007-től azonban főképp azt a kérdést kívánják megválaszolni, hogy a díjbevétel mekkora része kötődik az egyes értékesítési csatornához - mi is ennek alapján hasonlítunk.
A korábbi általunk használt CEA-statisztika [4] tehát 2007-es adatokkal dolgozik, a későbbi [5] pedig 2012-esekkel.

Az európai országokat három csoportból választottuk, ezek a meghatározó, nagy országok (Németország, Franciaország, Egyesült Királyság, Olaszország), a 10 millió lakos környéki kisebb régiek (Ausztria, Portugália), valamint az új EU-tagok (Szlovénia, Szlovákia, Románia és Horvátország)

Az egyes közvetítői kategóriák használata sajnos nem egységes, de a nagyságrendeket, illetve a változás tendenciáit jól mutathatják.

Az egyes kategóriákról:

- Közvetlen jegyzések (direct writing): jellemzően a biztosítók saját, jellemzően munkaviszony keretében foglalkoztatott munkatársai által jegyzett ügyletek.

- Ügynökök: Alkuszi státussal nem rendelkező, általában kizárólagosan egy biztosítótársaság számára dolgozó biztosításközvetítők.

- Alkuszok: Alkuszi státussal rendelkező, több biztosító termékeit értékesítő, független biztosításközvetítők.

- Banki értékesítés: Bankassurance modell keretében, általában a bank épületében, a bank munkatársai által végzett biztosításértékesítés.

- Egyéb: az előbbiekben fel nem sorolt kategóriák, főként a direkt marketing útján, illetve telekommunikációs eszközök használatára épülő biztosításkötés.

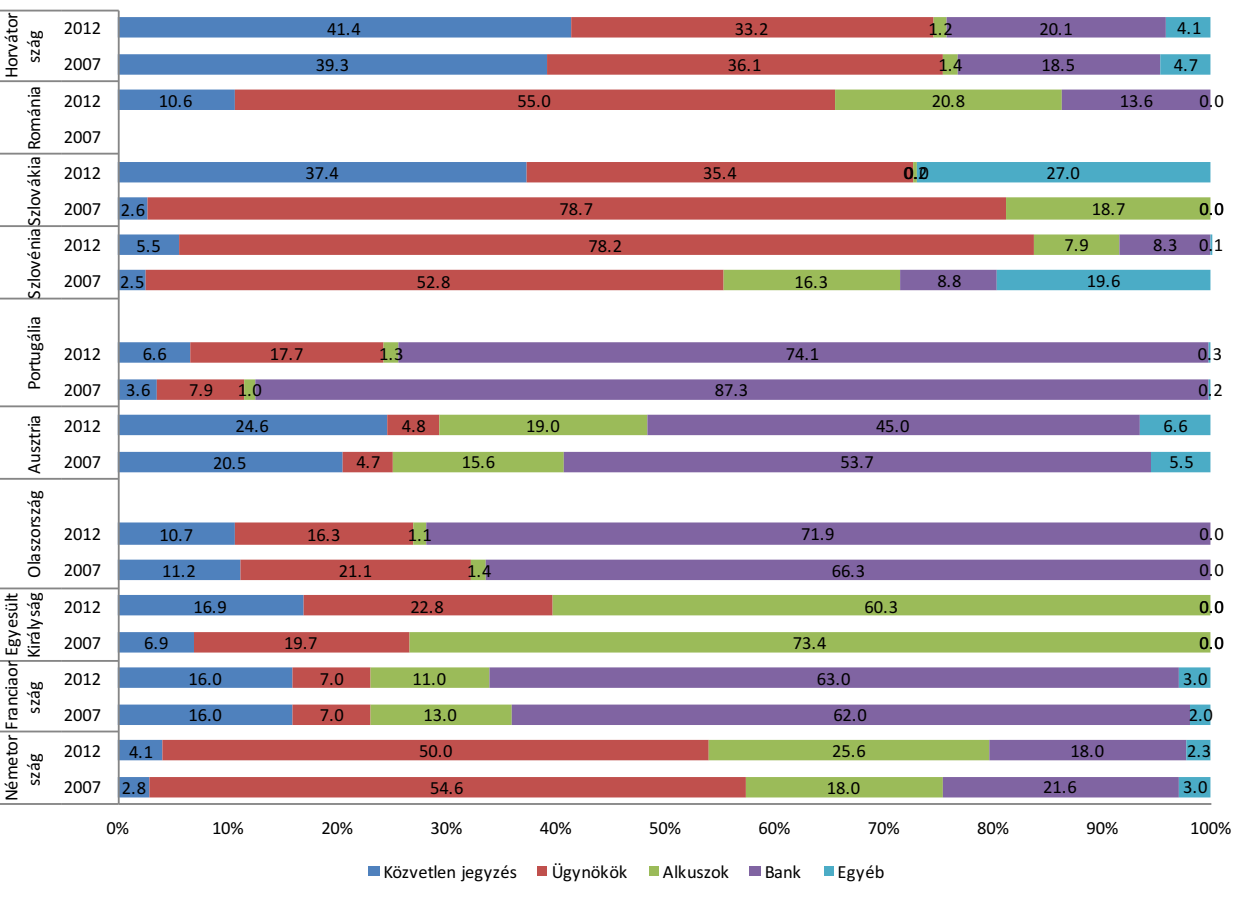

4. ábra: Azéletbiztositási dijbevétel megoszlása egyes EU-országokban, 2007-2012 (Forrás: CEA kiadványok alapján saját számitásel) 


\section{A táblázatból az alábbiak olvashatók ki:}

- A régi tagországokban:

- Anglia és Németország kivételével a régi tagországokban mindenütt meghatározó a bankok szerepe.

- Németországban inkább az ügynöki csatorna, míg Angliában inkább az alkuszok szerepe a meghatározó.

- Érdemes kiemelni Németországban a vizsgált időszakban a bankok és az ügynöki csatorna arányának csökkenését az alkuszi csatorna arányának növekedése mellett, míg az Egyesült Királyságban éppen fordított tendenciát figyelhetünk meg, az alkuszok által közvetített bevételek aránya csökkent le a közvetlen jegyzésekkel és az ügynöki csatornával szemben. Olaszországban a banki csatorna súlya nőtt.

- A kisebb országokban 2007-ről 2012-re visszaesett a bankok szerepe, az ürt a közvetlen ügyletek mellett Ausztriában inkább az alkuszok, Portugáliában inkább az ügynökök töltötték be.

- Ausztriában magas a közvetlen jegyzések aránya, ez leginkább arra vezethető vissza, hogy Ausztriában jelentős maradt a kizárólagos közvetítők munkaviszonyban való foglalkoztatása, más országokban azonban ezt inkább a vállalkozói jogviszony váltotta fel.

- Az új tagországokban

- Az ügynöki csatorna szerepe jelentősebb, kisebb viszont a bankoké és az alkuszoké.

- Nagyobbak a változások 2007-ről 2012-re, amit okozhatnak valóságos események, de akár módszertani változások is.

A kisebb országméretek, a fejletlenebb gazdaságok, illetve a nem túl régi állami monopolhelyzetek következtében előfordulhat, hogy egy kisebb országban egy nagyobb társaság berendezkedése a piac egészén is látható nyomokat hagy (Horvátország, Szlovénia).

\section{A nem-életbiztosítást illetően az alábbiak mondhatók el:}

- A régi tagországokban

- Általában (Olaszországot kivéve mindenütt) magasabb a közvetlen jegyzések aránya, mint az életbiztosításnál, ami a vagyonbiztosításoknál eleve magasabb technikai kompetenciaigényre vezethető vissza.

- Németországban, Olaszországban és Portugáliában az ügynöki csatorna, Angliában az alkuszi csatorna súlya a meghatározó, jelentős hasonlóságot mutatva az életbiztosítási megoszlással.

- Az egyéb csatorna aránya valamivel magasabb, mint az életbiztositás esetében (főként gépjármü- és utasbiztosítások).

- Az új tagországokban

- Szlovénia és Szlovákia erős ügynöki csatornákat mutat, míg Romániában 2012-ben kiegyenlítettebb az egyes csatornák aránya. Horvátország esetében a közvetlen jegyzések magasak, ami vélhetően a zömében társadalombiztosított ügynöki rendszerre (vagy legalábbis a piacvezetőnél ilyen dominanciára) vezethető vissza.

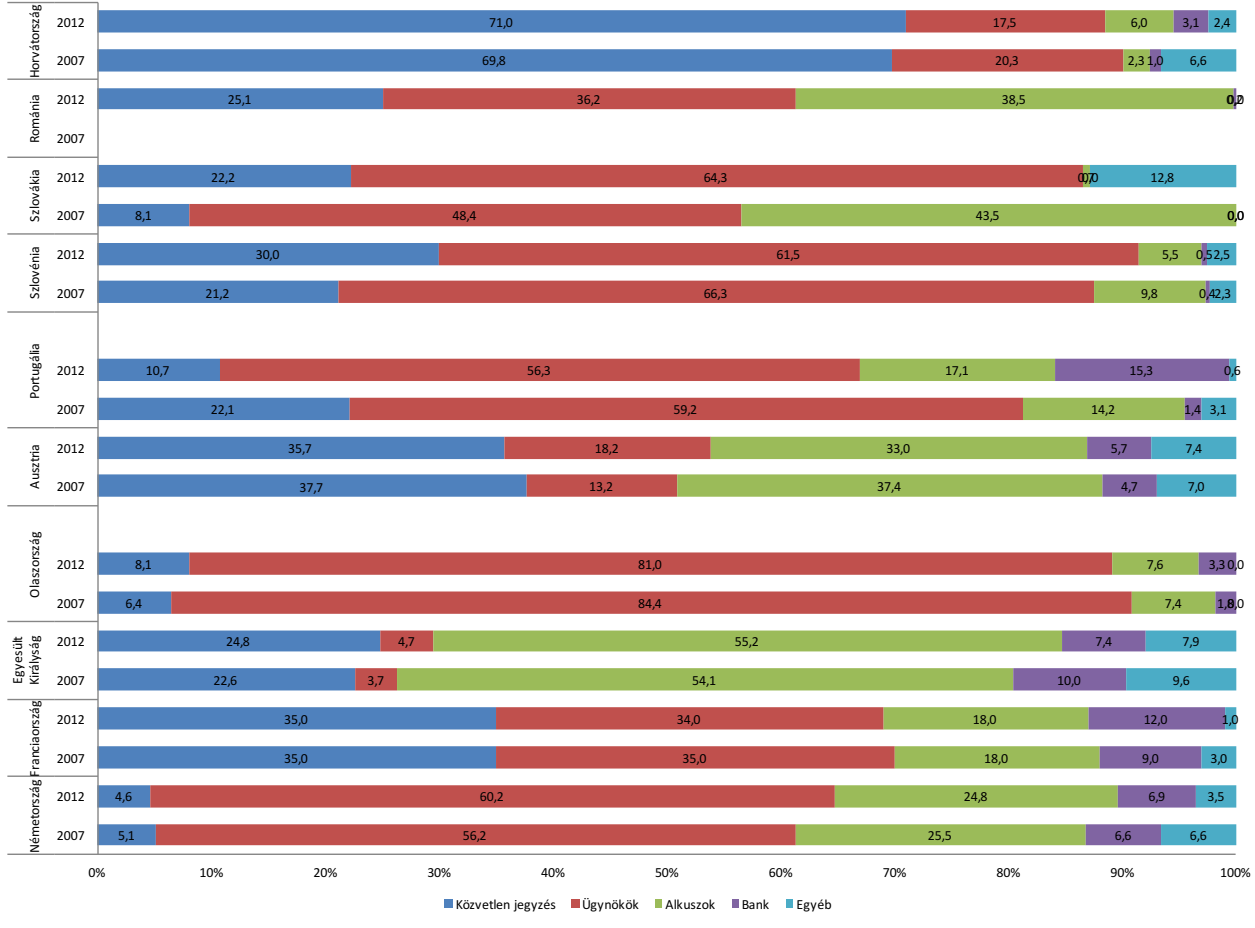

5. ábra: A nem-életbiztositáasi dijbevétel megoszlása egyes EU-országokban, 2007-2012 (Forrás: CEA kiadványok alapján saját számitások)

Jól látható, hogy a tendenciák eléggé ellentmondásosak, és csak korlátozottan alkalmasak alaposabb következtetések levonására, ami meglátásunk szerint főként az alábbiakra vezethetö vissza:

- adathiány (túl rövid adatsorok),

- adatmegfelelőségi problémák (az értékesítési csatornák erejét a díjbevétel helyett feltehe-

tően helyesebb volna az új értékesítések megoszlásával vagy e két mérőszám együttesével vizsgálni),

- a vizsgált időszak történeti karaktere (2008-tól elhúzódó válság).

Ez utóbbit meghatározónak tartjuk - meglátásunk szerint a válság két alapvető hatást gyorsított fel:

- a „megbízhatóbb” értékesítési csatornák felértékelődését a kockázatosabbakkal szemben, illetve

- az olcsóbb csatornák térnyerését a drágábbakkal szemben.

Ezek a hatások országonként eltérő mértékben részben támogatták, részben gyengítették egymást, az egyes hatások erejét pedig jórészt a válság előtti értékesítési szerkezet és az egyes értékesítési csatornák beágyazottsága határozta meg. 
A korábbi megbízhatóság válságbeli pozitív visszaigazolására vonatkozóan több példa látható: ilyen például a banki értékesítésü életbiztosítás arányának növekedése Olaszországban és Franciaországban, az ügynöki és alkuszi nem-életbiztosítások arányának növekedése Németországban és az Egyesült Királyságban, de elég sok ellenpélda akad az ellenkezöre is, így ezt a kijelentést nem tekinthetjük bizonyítottnak.

Hasonló a helyzet az olcsóbb csatornák válságidőszakban történő előnyben részesítésével - itt az új értékesítések adatai volnának szükségesek a pontos megítéléshez.

\subsubsection{Magyarország}

3.3.3.1. Magyarország sajnos hiányzik a fenti felsorolásból, hazánkban nincsen olyan rendszeres és hivatalosan publikált mérés, amely az egyes értékesítési csatornák teljesítményét megbízhatóan tükrözné.

\section{Szakértői becslés}

Szakértői becslések azonban itt is léteznek - egy általunk is reálisnak tartott becslés eredményét mutatja be az alábbi ábra:

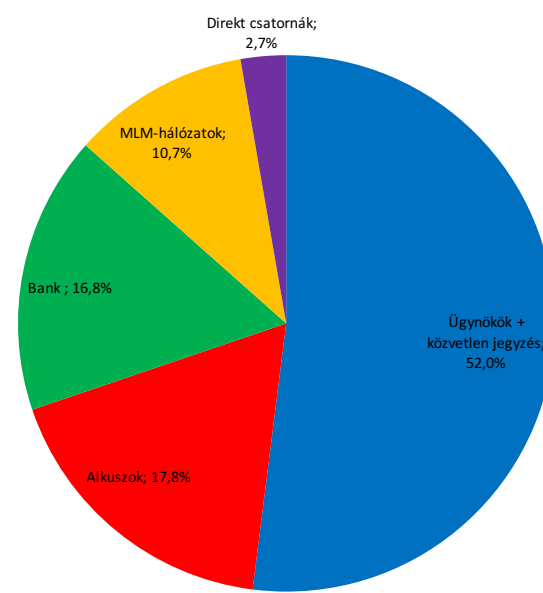

— Ügynökök + közvetlen jegyzés

- Alkuszok

Bank

MLM-hálózatok

Direkt csatornák

6. ábra: Az egyes csatornak súlyának becslese a magyarországi biztositási dijbevétellböl, 2012 (Forrás: Szakértő́i becslés-PEND Consulting Kfit)

A becslés szerint Magyarországon is az ügynöki csatorna dominanciája tételezhetö fel, a kelet-európaihoz képest némileg erősebb banki és számottevő alkuszi jelenlét mellett, összességében tehát hazánk jól illeszkedik a kontinentális európai modellbe.

\subsubsection{A kgfb - transzparencia és díjcsökkenés}

Magyarországon az online üzletkötés jelentős mértékben a kgfb-hez kötődik. Itt 2010-ig nőtt ekkor 1,3 milliónál tetözött -, azt követően csökkent az évfordulókor neten váltók száma, 2013-ban már csak 435 ezer váltóról számoltak be [1]
A kgfb átlagdíja az alábbiak szerint alakult:

\begin{tabular}{|c|c|c|c|c|c|c|c|}
\hline & 2007 & 2008 & 2009 & 2010 & 2011 & 2012 & 2013 \\
\hline Díjbevétel (Mrd Ft) & 133,044 & 129,476 & 129,336 & 118,006 & 92,270 & 81,342 & 81,053 \\
\hline $\begin{array}{c}\text { Átlagos gépjár- } \\
\text { múallomány (db) }\end{array}$ & 3788249 & 3902641 & 4109120 & 4134446 & 4025318 & 4025982 & 4168233 \\
\hline Átlagdij (1.000 Ft) & 35,120 & 33,177 & 31,475 & 28,542 & 22,922 & 20,204 & 19,445 \\
\hline Átlagdín változása (\%) & & $-5,5 \%$ & $-5,1 \%$ & $-9,3 \%$ & $-19,7 \%$ & $-11,9 \%$ & $-3,8 \%$ \\
\hline
\end{tabular}

7. ábra: A kgfb átlagdija és alkotóelemeinek alakulása 2007-2013 (Forrás: Feliugyeleti adatok [7], saját számitás)

A táblázat jól mutatja, hogy az egyes váltásokkal 2010-et követően egyre kevesebbet lehetett megtakarítani. Ezzel párhuzamosan a gépjármüállomány darabszámának $10 \%$-os növekedése mellett a kgfb üzletág díjbevétele 2013-ra a 2007-es szintnek mintegy 60\%-ára olvadt - a hatékonysági tartalékok tehát jelentősen lecsökkentek.

Ez tehát azt jelenti, hogy az alkuszok által használt infrastruktúrán igénybe vett online biztosításkötés az összehasonlíthatóság és a tömeges igénybevétel lehetösége miatt láthatóan hatékonyan fogyasztja az árazásban rejlö tartalékokat.

Az elemzett országstatisztikákkal az olcsóbb csatornák preferálása nem volt alátámasztható, a kgfb-példa azonban egyrészt megerösíti a kijelentést, másrészt megmutatja a módszertani korlátokat is - az adott szegmens díjbevétele éppen a csatornaváltás miatt csökkent, a díjbevétel-megoszlás kizárólagos vizsgálata így éppen a lényeget, a csatornaváltás miatti díjcsökkenést fedi el, láthatóan szükség van az új szerzések megoszlásának vizsgálatára is (darabszámok és értékek).

\section{Az alkuszok által használt online biztosításkötés láthatóan}

hatékonyan fogyasztja az árazásban rejlö tartalékokat.

\subsection{Még egyszer a szabályozásról}

Az európai és a magyar szabályozás többféle motivációjú, ebből legalább négy markánsan megkülönböztethető:

- Állampolgári és gender-egyenlőség növekvő súlya: Ezt a magyar és európai szabályozás korábban hajlamos volt alábecsülni, aminek a következménye a gender direktíva eredeti szellemiségével, a nők hátrányos helyzetének felszámolása céljával éppen ellentétes hatású, a nők számára növekvő kockázati díjakat eredményező életbiztosításidíj-szabályozás kialakulása lett [21]. 
- Az EU mint egységes piac elvének kibontása, ami leginkább az áruk és szolgáltatások szabadságának megélhetőségében (pl. határon átnyúló szolgáltatások támogatása) és a szolgáltatási szabadság határainak csökkentésében, így például a közvetítés szabályozásában ölt testet.

- A közös európai szabályozás és a nemzeti jogrendszerek működőképes együttélése: Ez leginkább a konszenzus és a megvalósíthatóság együttes fontosságát jelenti - alaposan átbeszélt elveket tükröző rendeletalkotás és kellő határidő a tagállami alkalmazásra. Ennek a szabályozási elvnek a működésére jó példa a Szolvencia II. bevezetése - ez az eredeti határidőhöz képest több évet csúszott, és a végrehajtás következetessége sem egészen egyértelmű, mindazonáltal a célok megvalósulása a hosszú és transzparens bevezetési folyamattal - a szolgáltatók pénzügyi erejének kockázat-adekváttá, valamint a biztosítási rendszer egészének stabilabbá tétele - összességében sikeresnek mondható.

- Növekvő súlyú és elismert akarat a már említett fogyasztóvédelem erősítése, amely az érdeksérelem/jogsérelem megelőzésétől széles spektrumon keresztül a jogérvényesítés megkönnyítéséig terjed. Az érdeksérelem megelőzésére szolgál például a MIFID-szabályozás kiterjesztése a befektetéssel kombinált biztosítási termékekre is, amely többé-kevésbé igyekszik összhangba hozni az ügyleti kockázat érthetőségét az ügyfél pénzügyi képzettségével vagy a misselling-motivációt csökkentő hatással az IMDII/IDD, a jogérvényesítés megkönnyítésére pedig az elállás jogintézményének térnyerése emelhető ki.

A fentiek jól láttatják, hogy a biztosítás esetében a közvetítési kérdés súlya növekvő: az IMD, a MIFID, az IMD II/IDD PRIIPS európai projektek egyaránt a 2000-es évek termékei.

Hasonló következtetésre juthatunk a statisztikákat vizsgálva: a régi tagországok mérési módszertana egyre kifinomultabbá válik, a mérésekkel rendelkező országok köre pedig szélesedik.

\subsection{IT kihívások}

A fentiek alapján a mindenkori biztosítási informatikával szemben legalább két nagy kihívás azonosítható:

- a hagyományos informatikai szerepeknek való megfelelés, azaz a sztenderd biztosítási folyamatok támogatása a pontosabb, gyorsabb és olcsóbb végrehajtás érdekében

- az ügyfelekkel szorosabb kapcsolatban állók - főként a biztosítóval kizárólagos értékesítési viszonyban levő ügynöki csatorna - számára olyan megoldások szállítása, amelyek alkalmasak arra, hogy a technológiai fejlődés újabb eszközeit, alkalmazásait jól kezelő, zömében fiatalabb célközönséget is eredményesen lehessen megszólítani, üzletiesen szólva „részévé kell lenni az üzletnek.”

Érdemes tisztázni, hogy a felgyorsult generációváltozás szolgáltatói kezelése nem elsődlegesen IT feladat! Másfelől azonban a biztosító szokásos szervezeti egységei közül a marketing mellett az IT az, amelynek segítségével talán a legjobban érthetők meg a felgyorsult technológiai fejlődés következtében bekövetkező társadalmi és generációs viselkedésváltozások.

\section{Egy speciális alkalmazás: jutalékkezelő rendszer és értékesítéstámogatás}

Az értékesítéstámogatásnak egy része maga a termékstruktúra, amelyet a közvetítői hálózat értékesíthet. Alapvető elvárás, hogy az új termékek lehetőleg minél gyorsabban kerüljenek piacra - ez azonban már nemcsak üzleti, hanem informatikai kérdés is. A time-to-market, vagyis a piacra kerülési idő lerövidítése nagyon erős tényező, ha egy új termék vagy új konstrukció fejlesztése már megtörtént.

Fontos az is, hogy az értékesítők milyen informatikai és egyéb támogatással vannak ellátva. Ha valaki egy tableten keresztül be tudja mutatni az adott biztosító portfólióját, és ebből egyszerűen, hatékonyan segítve ki tudja választani az ügyfélnek legmegfelelőbb biztosítást, akkor ez nagyon jó informatikai támogatás. Ha a közvetítő ehhez kapcsolódóan megfelelő képzésben részesül, ez egy másik olyan érték, amelyet magával tud vinni az értékesítésbe. Ezt egészíti ki a jutalék, amely természetesen az egyik fö ösztönző erő

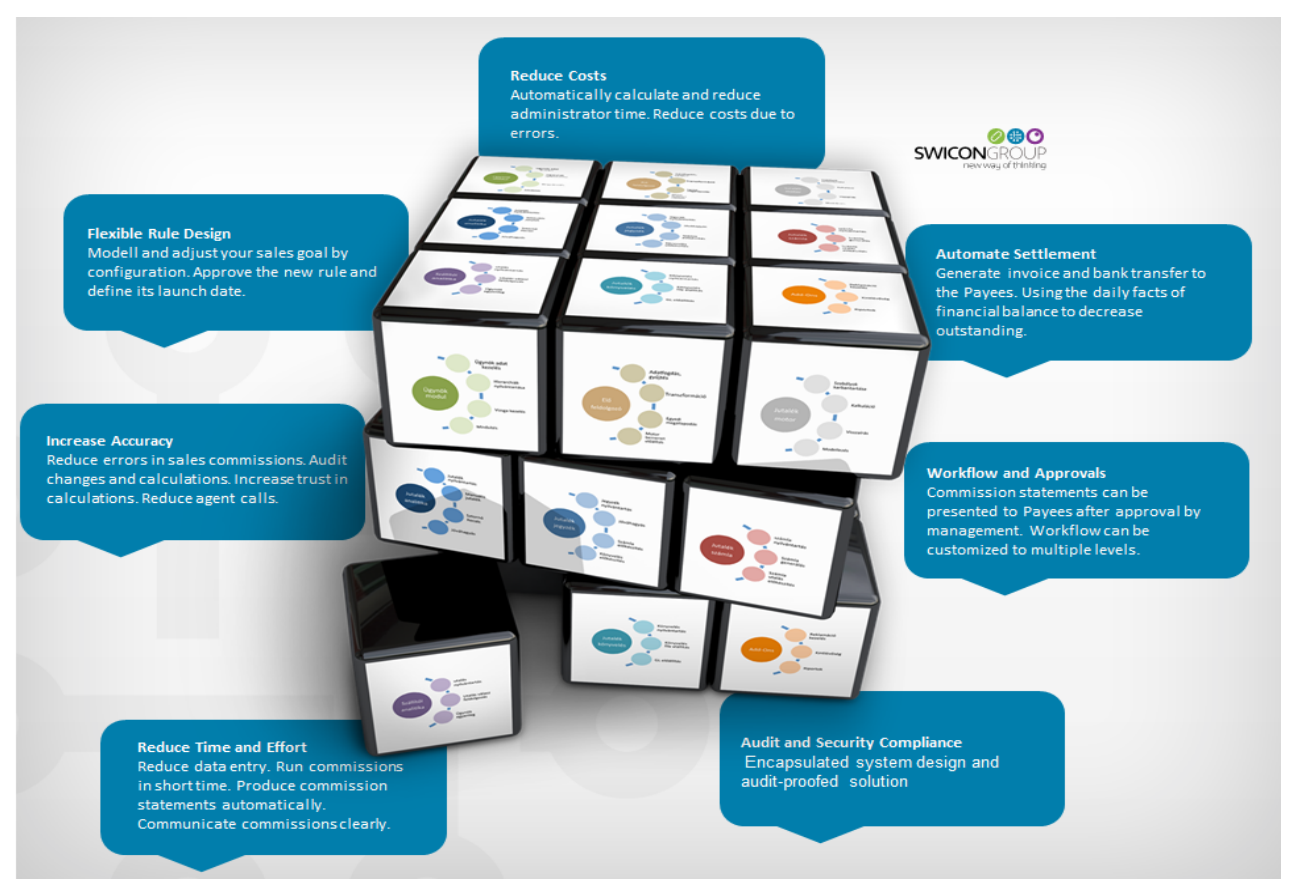

8. ábra: : A jutalékrendszerrel szemben támasztott követelményekés azokat kielegittó funkciók (Forrás: Forrás: saját gyüjtés)

Az értékesítési csatornák diverzifikálódása módosítja a jutalékrendszerrel szemben támasztott követelményeket is. A hagyományos elvárások szerint az jelenthető ki, hogy annál jobb egy jutalékrendszer, minél könnyebben bele lehet illeszteni az ösztönzőrendszer meghatározó elemeit. Ehhez társul egyfajta növekvő rugalmassági elvárás is; eddig is rugalmasnak 
kell lennie a kifizetésnek, másfelől azonban ma már gyorsabban és rugalmasabban kell alkalmazkodni a korábbinál gyorsabban változó termékstruktúrához, illetve a vállalati alkalmazkodás kapcsolódó informatikai megvalósításaihoz is.

A mai biztosítói informatikai rendszerrel szemben már nemcsak az a követelmény állítható fel, hogy „kövesse le” mindazt, amit az ügyfelek és az üzlet szeretne, hanem az is, hogy váljon magának az üzletnek is az eszközévé.

Ahogy nő a diverzifikáció, úgy értékelődik fel a belső döntések támogatásának kérdése, a szcenárióépítések támogatása. A döntési helyzetek kimeneteinek elemzése nem nélkülözi a jutalékra vonatkozó előrejelzéseket sem. A jól tervezett jutalékrendszer tehát fontos vezetési eszköz, és segíti a társasági értékesítési stratégia megvalósítását.

Ha a modellezés funkciója is megjelenik egy ösztönzőrendszerben, és az visszakapcsolódik a termékfejlesztéshez, akkor eljutunk egy olyan komplex informatikai és üzleti háttértámogatáshoz, amelyben egy új termék bevezetése és megjelenítése mind bevétel és kifizetés oldalon, mind fejlesztés, marketing és értékesítéstámogatás oldalon, mind képesség és tudás oldalon feladatokat, költségeket és hasznokat jelent. Egy ilyen rendszerben az elemek egymásra hatnak: látjuk, hogy milyen hatása van egy termék bevezetésének, és mi történik, ha azt megváltoztatjuk. Ennek segítségével lehet tervezni, modellezni és kipróbálni újításokat. Ezzel pénzt és esetleges kudarcokat is megtakaríthat a biztosítótársaság.

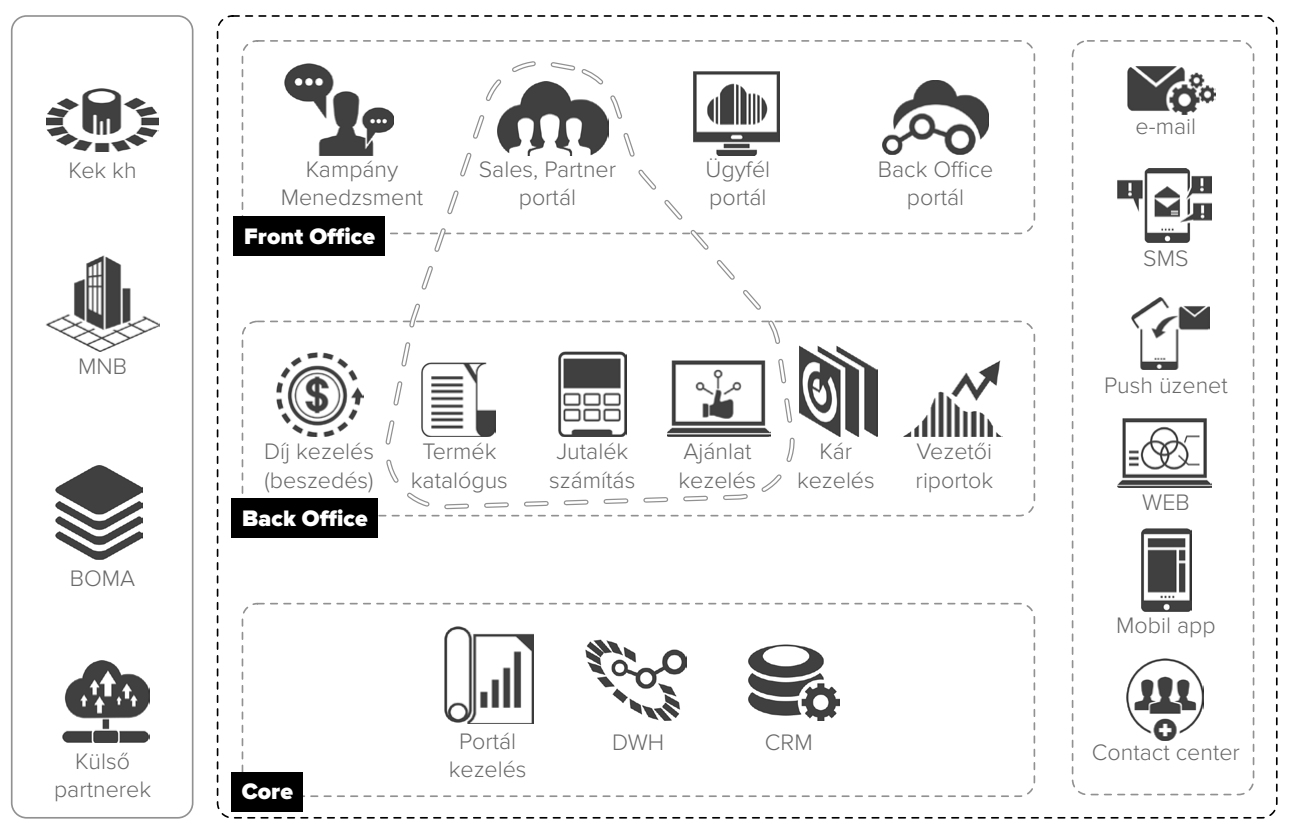

9. ábra: : A jutalékrendszer által kapott és küldoôtt adatok és a biztositó adatvagyonának kapcsolata

(Forrás: saját összeállitás)
4.1. Az alapok: jutalékrendszer és adatvagyon-gazdálkodás

A jutalékrendszer szoftvere általában a termékekhez kapcsolódó leíró tulajdonságokkal, illetve az értékesítőhöz kapcsolódó információkkal dolgozik. Ez egészül ki az egyes szerződésekhez, illetve azok állapotváltozásához kapcsolódó információkkal tehát a teljes adatbázisba szerződésinformációk, termékinformációk, dijjinformációk, ügynökinformációk és hierarchiainformációk kerülhetnek bele, ezeket különböző rendszermodulok kezelik.

Ezek alapján már fel lehet térképezni, hogy melyek azok az adatok, amelyek egy konkrét jutalékot, konkrét jutalmazást befolyásolnak. Ezt az adatbázist érdemes akkor is karban tartani, ha az informatikai rendszere nem teljes funkcionalitású.

A fentiek nyilvánvalóvá teszik, hogy a sok pénzbe kerülő adattárházak „elöszobája” a jutalékrendszerrel kapcsolatos adatvagyon rendszerezése és folyamatos karbantartása. A jutalékrendszerrel kapcsolatos adatvagyon-összegyüjtést és folyamatos karbantartást kialakítani szándékozó projekt tehát egyben az adattárház-projektek pilotjaként is felfogható, azzal a kiegészítéssel, hogy a projekt hasznosíthatósága itt sokkal közvetlenebb.

Ha a szükséges információk megvannak, akkor lehetőség nyílik arra, hogy egy adattárház épüljön, lehetőséget nyújtva arra, hogy az üzleti tudás, az üzleti információk egy helyre kerüljenek. Így a modellezéshez szükséges adatok áramlása gyorsul, időt, pénzt és erőforrást takarítva meg a biztosítónál.

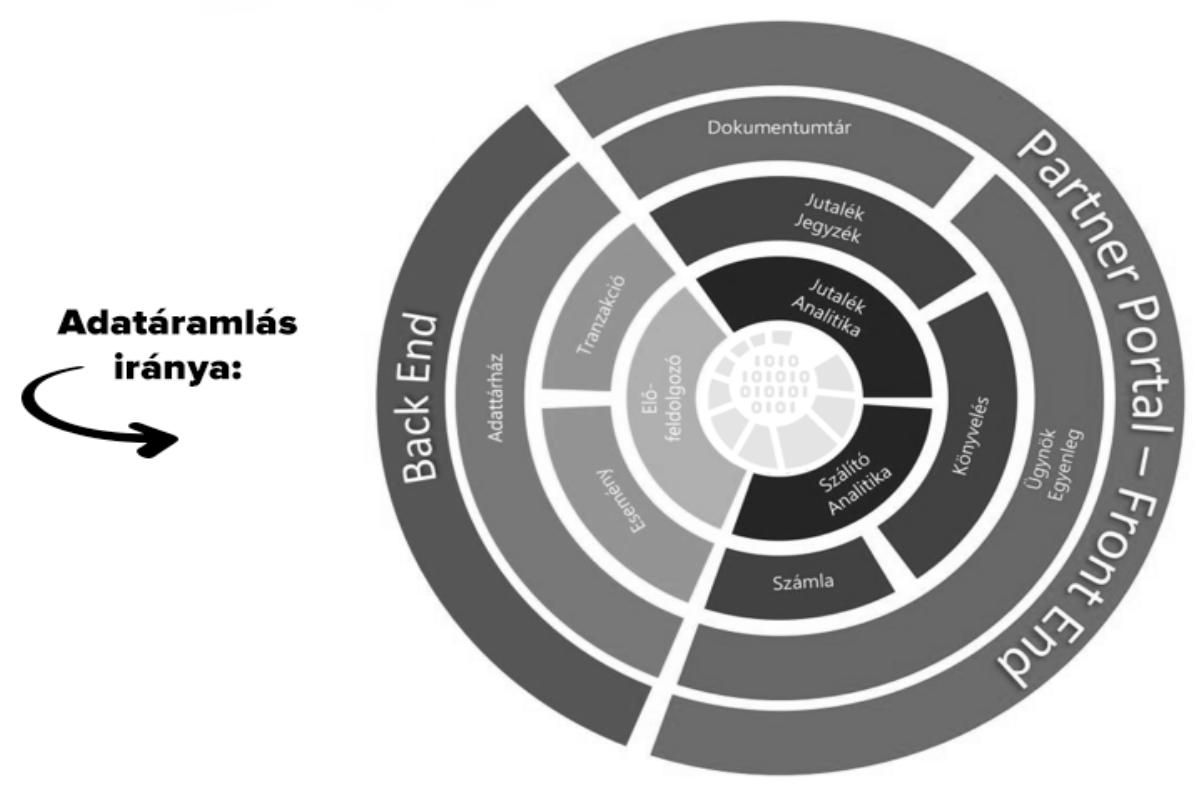

10 ábra: : Architektúrarétegekés adatáramlás a backend rendszerektól a frontend rendszerek felé (Forrás: saját összeállitás) 
A közvetlen ajánlatkezelési, termék-, illetve közvetítőadatokat tároló alkalmazásokon túl érdemes megemlíteni két olyan alkalmazást, amelyek átgondolt kapcsolata a jutalékrendszerrel nem evidens, ugyanakkor a kapcsolat átgondolt alapokra helyezése hozzásegíthet a fenti adatvagyon-gazdálkodás kialakításához, illetve feltétele az esetleges későbbi adattárház-projekteknek. Ez a két alkalmazás a szerződéskezelő rendszer és a kárrendszer.

Mindkét esetben kijelenthető, hogy a jutalékrendszerrel való átgondolt kapcsolat támogatja és könnyen megvalósíthatóvá teszi az elemzési lehetőségeket, segíti a javaslattételeket az árazási és kockázatelbírálási elemek irányába, valamint irányt szabhat az értékesítés ösztönzésének is.

Az így megnövelt elemzési képesség szükségessége a biztosító ügyfélkörének, termékválasztékának és értékesítési csatornáinak komplexitásával egyenesen arányos.

\subsection{Innovációs kísérletek az értékesítésösztönzésben}

Jól látható, hogy a jutalékrendszer kapcsán mindkét kihívástípussal szembesülünk: az alapvető célt, az üzletkötésért járó jutalékok kifizetését garantálni kell egy növekvő komplexitású vállalati és szabályozó környezetben (követelmények), illetve támogatni kell a jövőbeni - elsődlegesen piaci indikációjú - alkalmazkodásokat is (kapcsolódási lehetöségek).

\subsubsection{A belső és szabályozói környezethez való alkalmazkodás követelménye}

A biztositók belső informatikai rendszerének tervezése, kiépítése és karbantartása egyértelműen IT-feladat, tipikusan ide tartozik a jutalék- és ösztönzőrendszer is.

A jutalékrendszer főképp közvetítőkre vonatkozik, tehát az ügynöki adatok karbantartásának és az értékesítési hierarchia menedzsmentjének funkcióját is betölti. Ebben a modulban benne kell lennie mindenki adatainak, aki jutalékfizetés szempontjából szóba jöhet. A modul rendelkezik olyan előtét-alkalmazással is, amely az összes folyamatbeli szinkronizálást megvalósítja a jogosultság igénylésétől az ügynökigazolvány nyomtatásán át a vizsgáztatásig, tehát az ügynökké válás folyamata is integrált része a rendszernek.

A jutalékrendszer kezeli tehát az ügynökhierarchiát, a szervezeti hierarchiát (nemcsak ügynök típusú közvetítők), a mentorálási hierarchiát (átmenetkezelés) és az elszámolási hierarchiát (többes hozzárendelések) is. A rendszerben természetesen meg lehet adni a jogosultságokat is, lehet kontrollálni, hogy az ügynök csak a saját adatait lássa, vagy az alá tartozó ügynökökét is. Másfelől az adminisztrátorok láthatják a hierarchiákat, de nem látják az egyes ügynökök értékesítési adatait.

A hatékony jutalékozáshoz szükséges minden kapcsolódó adatot gyorsan és pontosan megkapni, ezért az elszámoló rendszernek a portfóliórendszerektől függetlennek kell lennie. Fontos azonban, hogy az elszámoló rendszer adatszinten összekapcsolódjon a többi rendszerrel vagy az adattárházzal, az így megkapott adatokhoz társíthatja azokat az eseményeket/ információkat, amelyekhez kapcsolódóan jutalékot kell kalkulálnia. Ezután az eredményeket olyan egységes formátumra hozza, amellyel a jutalékot az általános szabálymotorral ki lehet kalkulálni. Minden biztosítótársaságnál vannak egyedi szabályok is - a jutalékrendszernek ezeket is kezelnie kell.

$\mathrm{Az}$ adatok integrációja alapvetően automatikus, csak a szabályokat kell beírni, ezt viszont könnyen megteheti a központi értékesítéstámogatási egység vagy akár az informatika, attól függően, hogy milyen típusú adatokról van szó. Az eredmények ezután a jutalékanalitikában jelennek meg, amely az ügynök számára transzparens, vagyis megtekintheti, hogy éppen hol áll most, illetve mi a helyzet a folyamatban levő ügyletekkel. Ezáltal a reklamációkezelést is támogatja a rendszer, illetve ha nincsen reklamáció, akkor az automatikus számlázást is lehetővé teszi.

\subsubsection{A jövőbeni alkalmazkodások támogatása}

\subsubsection{Modellezés, szcenárióépítés}

A jutalékkezelő rendszer fontos eleme a modellezés, szcenárióépítés támogatása. Amennyiben a szabálymotor konfigurációjában változás történik, az hatással van a társaság bevételeire is. Ezzel a funkcióval a jutalékrendszer meg tudja mutatni, hogy az egyes változások milyen eredményekkel járnak, illetve létezik egy ügynöki munkát segítő modellező modul is.

A modellezést a biztosítótársaság tehát egyrészt a stratégiai tervezésben használhatja (vállalati), másrészt az operatív tervezésnél (értékesítéstámogatás), illetve használhatja a biztosítási ügynök is a saját jövedelemtervezéséhez - mindez a jutalékrendszerekkel kapcsolatos szakmai gondolkodásnak eddig nem volt integráns része.

\subsubsection{A bizalom és az online tér lehetőségei}

Látjuk a telekommunikáció fejlődését - hosszú idő telt el az egyes beszélgetéseket kézzel kapcsoló telefonos-kisasszonyoktól a roaming-díjak EU-n belüli eltörléséig [6]. Láttuk, hogy a szabályozás változása jelentős kihívást jelent a közvetítésre irányuló, azt súlyponti elemként tekintő tevékenységeknek.

4.2.2.1. Kétségek: A bizalom forrása még mindig a személyes kapcsolat?

Korábban - ahogy ezt az USA kapcsán láttuk - a bizalom elsődlegesen személyekhez, illetve intézményekhez kötődött. Másfelől azt is látjuk, hogy a generációs változások gyorsulnak, egyre kevesebb az egymásra (személyekre) fordított idő, viszont nő az életünkben a digitális eszközök szerepe, mindez pedig nem hagyja érintetlenül az olyan személyes viszonyokra alapozott tevékenységeket sem, mint a biztosítás, illetve a biztosításközvetítés. A biztosításoknál az internet létjogosultsága magától értetődő (egyes termékeknél - például autóbiztosítások - különösen), és azt is látjuk, hogy az online világ térnyerése folyamatos.

Lehet, hogy az egyes alkalmazások iránti bizalom nő meg olyan mértékben, hogy alkalmasak lesznek a tájékozódás segítése és az összehasonlítás sikere [27] mellett akár egy személyes pénzügyi viszony létrehozására is? 
Nem tudjuk, hogy ez így történik-e, és arra vonatkozóan sincsenek információk, hogy ha igen, akkor mi lesz a biztosításközvetítéssel? Vajon a maihoz hasonló felállás szerint szükség lesz közvetítőre, aki jutalékot kér, vagy a jelenleg egyébként is gyakran online végzett tájékozódás és a személyességmentesség növekedése következtében az „ügynökmentes értékesítés” nyer további teret, esetleg hüségkedvezménybe csomagoltan [17]?

Nincsenek biztos válaszaink, mindössze az a sokak által osztott bizonytalan érzés, miszerint ezek a kérdések aktuálisabbak, mint valaha.

A biztosítóknak ma már nemcsak azért kell ezzel foglalkozniuk, mert lehetőség, hanem azért is, mert kényszer - az online térben jelen vannak a potenciális ügyfelek mellett a jelenlegi versenytársak is.

Ma már inkább a tudatos távolmaradás igényel nagyobb bátorságot, mint a részvétel.

Az online értékesítés és a közösségi média tehát olyan terület, ahol bizonytalan sikeresély mellett nagy fejlesztési potenciál szükséges a biztosítók számára.

Az internet egyik legáltalánosabb és legismertebb eleme az, hogy olyan felhasználói élménnyel, olyan webes felülettel találkozik a vásárló, amely felkelti a figyelmét, így versenyelőnyt élvezhet az, akinek ilyen felülete van. Másfelől ez egy „zajos” terület - rengeteg az alkalmazás, a platform, sok a felület, lényeges az internetes keresőmotorok működésének helyes ismerete, tehát a jó megjelenéshez további online marketing eszközöket kell hozzárendelni. Ma azonban már mindenki különböző online profilokkal bejelentkezve kommentel, csetel, megoszt vagy twítel, használja a közösségi médiát, ami egyrészt jól azonosíthatóvá teszi a potenciális vásárlókat, másrészt megfelelő hátteret ad a biztosítók online fejlesztéseihez is.

Felértékelődik tehát a nagytömegű adatok kezelése, a helyes szűrések, elemzések, profil- és csoportképzés, illetve a válaszok arra a kérdésre, hogy miként lehet egy adott profilú csoport számára egy terméket, szolgáltatást vonzóvá tenni és értékesíteni.

\subsection{Big Data}

Nagy tömegű adatok elemzéséből olyan adatokat, valószínűségeket, korrelációkat állapíthatunk meg, amelyeket eddig nem fedeztünk fel, amelyek esetleg az adott termék, szolgáltatás - adott esetben biztosítás - iránti érdeklődésre vagy annak értékesítésére is hathatnak. Feltehetjük a kérdést másként fogalmazva is: online profil alapján milyen termékekkel érdemes megcélozni egy potenciális vásárlót?

Ezek általában méretekhez kötött eljárások, emiatt nem elsősorban Magyarországon, illetve a piacok nemzeti karaktere miatt még csak nem is az Európai Unióban alkalmazott eszközök. Bár európai alkalmazásra is vannak példák, a nagy mennyiségű adatelemzéseknek föképp az USA biztosítási piacán van hagyományuk.

Fontos, hogy a Big Data elemzések üzleti alkalmazásaihoz az eddig említett marketingoptimalizáción, az információelemzésen és a tudásmenedzsmenten túl gyakorta társulnak egyéb szempontok is. Ilyen például az erősödő adatvédelmi, compliance szempontok - nem mindegy, hogy a közösségi platformok korában a saját munkatársak hogy kommunikálnak a társaságról, hogy védik az üzleti titkokat, stb. -, ez a szempont érezhetően felértékelődik [20].
De megemlíthetők az ügyfél-kommunikáció lehetőségei is - a „mindencsatornás” jelenlét egyértelmü üzleti előny, egy adott elégedetlen ügyfél Facebookon leírt netes panasza akár azonnal is orvosolható, és a további panaszok is nagy valószínűséggel megelőzhetők.

Ezek új kihívásokat állítanak az eddig alkalmazott megoldások elé, nemcsak az elemzési- értékelési eszköztárt illetően, hanem felértékelik a célzott kereséseket is (adott profillal rendelkező potenciális fogyasztók), illetve a hagyományos funkciók, mint például a naplózások (biztonsági szempontok) kapcsolódási képességeit is.

A fenti kihívások új technológiák sorának létrejöttét eredményezték. A nagy tömegú adatok értékelését illetően kiemelhetők például a NoSql megoldások, amelyek költséghatékonyan módosíthatók és üzemeltethetők. A MetLife Wall, Hadoop már kiforrott technológia, a Lucene motor a fuzzy search-csel a célzott keresést valósítja meg nagy, nem strukturált adathalmazon. A közösségi alkalmazásokhoz való illeszkedés fontosságát mutatja az ebben jelentőset alkotó kisebb fejlesztőházak iránti Big Data-szereplők általi kereslet is.

\subsection{Szegmentáció}

Az eddig leírtakkal illusztráltuk, hogy a biztosító és informatikai rendszere számára olyan információk tárolhatók el, amelyekkel az adott alkalmazásba belépett felhasználókat viselkedésük alapján különböző szegmensekbe, csoportokba lehet besorolni, illetve sorrendet lehet hozzájuk rendelni a mutatott érdeklődés alapján (melyek azok a termékek, amelyek érdekelhetik, illetve melyek azok, amelyeket feltehetöen megvenni is hajlandó lenne). Például ha valaki sokszor nézeget külföldi utazásokhoz kapcsolódó honlapokat, akkor neki életbiztosítás helyett balesetbiztosítást célszerű ajánlani. Ha nagyon sokszor síel, akkor egy speciális utasbiztosítást, amely a síeléshez is alkalmas. Ha valaki többször olvas időskori előtakarékossághoz kapcsolódó cikkeket, akkor nyugdíjterméket érdemes ajánlani neki, még akkor is, ha most aktuálisan a böngészőben nem ezt nézi, hanem egy sportcsatornát. Ezek az információk mind megállapíthatók egy-egy felhasználóról a szegmentáció segítségével.

Másfelől van olyan informatikai megoldás is, amely nemcsak szegmentációt végez, hanem a használat alapján öntanuló, vagyis fejleszti azt, hogy sikeresebb legyen az online felület. Az öntanuló algoritmus általában kétféle lehet:

- a viselkedést monitorozó, tehát ha látja a program, hogy a leendő vevő ide kattintott, de máshova egyáltalán nem, akkor tudja, hogyan kell átalakítani az online felületet.

- a mesterséges intelligenciát használó; itt a különböző (pl. Facebook) kommentek alapján szürik, hogy mik az értékesítéshez használható információk, illetve azokat, amelyek magát a termékpaletták vagy az értékesítés hatékonyságát tudják javítani. Például egy alkalmazás kiszűri az információfolyamból, ha valaki csecsemőfotót posztol. Az ehhez küldött gratulációk mellé egy bővebb ismertetőt kap a felhasználó, amelyből megtudhatja, hogy Magyarországon van egy ún. babakötvény, amelyet ő is igénybe vehet. A babakötvény mellé akár előtakarékossági termék is kínálható például a gyerek egyetemi oktatási kiadásainak összegyüjtésére, megjelenhet a direkt termékkapcsolás. 
Ahhoz, hogy egy ilyen típusú online felület hatékonyan müködjön, vagyis pontosan mérje és kezelje ezeket az interakciókat, ezeket a programelemeket már az online felület megtervezésekor implementálni kell.

\subsection{Gamification}

Láttuk, hogy az egyes generációk életében a technológia, az online tér, az egyes alkalmazások használata egyre nagyobb szerepet játszik, és ehhez azt is hozzátehetjük, hogy ezek a „találkozások”, a modern/divatos technológiák és alkalmazások megismerése egyre korábbra tolódott, másrészt tanúi vagyunk a gyermekkor „megnyúlásának”, annak, hogy a felnőttkor kezdete egyre későbbi időpontra tolódik ki.

Ez, valamint a homo ludens-jelenség kellő alapot ad ahhoz, hogy az online marketingen belül a közösségi médiánál is egyre erősebb szerephez jusson az ember játékos énjének a felszínre emelése, a játékosságnak, a szórakoztató elemeknek a fokozott használata. Mindez tehát nem öncélú: a ,friss" potenciális ügyfelek életkora meglehetősen alacsony, a játékosság, a szórakoztató jelleg pedig különösen a fiatalabbaknál támogatja az odafigyelést, így az értékesítéshez kapcsolódó információk átadását, illetve megszerzését is. Erre a tevékenységre külön szakszó is keletkezett: Gamification. A Gamification (játékossá tétel) tehát azt jelenti, hogy üzleti eseményeket játékos köntösbe burkolunk, és próbálunk hatékonyabb eredményeket elérni, mint a klasszikus funkcióorientált megoldásokkal. A Gamification lényege, hogy kilépünk a szokványos, merev megoldásokból, és emberközpontúvá tesszük, közelebb visszük az életünkhöz azt a tevékenységet, amelynek mentén eredményeket kell elérnünk.

A Gamification hatékonyságát az adja, hogy a fokozott felhasználói élmény hatására vagy annak elérése érdekében a potenciális vagy már meglévő ügyfelek hajlandóak magukról több információt megosztani a biztosítóval. A Gamificationnel a vásárlók mellett a közvetítőkről is lehet olyan információkat feltérképezni, amelyeknek van hozzáadott értékük, a segítségével többletérték teremthető. Ilyen lehet például egy kompetencia felismerése, majd a felismert kompetencia felhasználása az értékesítési hálózatban. Például egy 3-5000 fös értékesítési hálózatban nem mindenkiről lehet tudni, hogy az alaptevékenysége mellett mihez ért, egy játékon belül azonban sokkal könnyebben megszerezhetők ezek az információk, mint ha kompetenciamátrixot töltetne ki alkalmazottaival a társaság.

\section{5. Összefoglalás}

A tanulmány elsődleges célja annak bemutatása, hogy a többcsatornás értékesítési modell terjedése, az egyes értékesítési csatornák digitalizációval kapcsolatos változása, illetve a digitális világgal szemben különösen a fiatalabb generációkban növekvő - a biztositási viszony forrásaként szolgáló - bizalom hogyan értékeli át a biztosítási informatika feladatát.

Az értékesítési csatornák európai elemzésénél azt láttuk, hogy a statisztikák ezzel kapcsolatosan nem állnak a megfelelő stabilitási szinten. Az adatsorok meglehetősen rövidek, az adatok kifejezőképessége is korlátos, illetve a vizsgált időszakban zajlott a 2008-as válság és az alkalmazkodás.

Meglátásunk szerint helytálló - bár adatokkal teljes mértékben nem igazolható - az a kije- lentés, hogy a vizsgált 2007-2012-es időszakban a nagyobb európai tagországokban megmaradt a korábban domináns, megbízhatóbb csatornák jelentősége. Európai adatokkal a válság okozta növekvő dijérzékenység sem volt igazolható, ám a magyar kgfb esete erős érv az állítás igaza mellett. Az említett példa egyben azt is megmutatta, hogy az alkuszi infrastruktúrán történő online értékesítés gyorsan felemésztheti a díjképzésben rejlő tartalékokat, illetve rávilágít a jelenlegi mérések gyengeségeire is.

A szabályozási kihívások elemzése kapcsán megállapítottuk, hogy a 2015. január 1-jétől hatályos változások elősegíthetik az értékesítés misselling-motivációktól való tisztulását, ügyfélbarátabbá válását. Úgy véljük, hogy ennek kapcsán a jutalékrendszernek elsősorban támogató feladata van, illetve felértékelődnek a modellezést, tervezést erősítő képességek is, az üzletkötők oldalán a jövedelemtervezést értve ez alatt.

Az USA hosszabb távú biztosítástörténetének tapasztalatai alapján úgy véljük, hogy ott a generációs változások markánsabbak, így feltűnőbb az a jelenség, hogy a piacra lépő generációk egyre kevésbé bizalmatlanok a digitális világgal szemben.

Nem tudható, hogy a bizalmatlanságnak ez a csökkenése olyan nagy mértékben átcsap-e bizalomba, hogy az a biztosítási viszony forrását is tömegszerüen képezhesse - ennek „előszobája”, a szolgáltatások összehasonlításával kivívott hitelesség azonban már adott.

A biztosítók informatikai felelősei - ezen belül pedig a jutalékrendszerekéi -, meglátásunk szerint, kettős kihívás előtt állnak. Egyrészt hagyományos módon támogatniuk kell a biztosítási folyamatokat, másrészt pedig mérlegelniük kell a viszonyulást ahhoz a kijelentéshez, hogy a digitalizácó térnyerésével az informatika már nemcsak „megoldásokat szállít”, hanem „az üzlet része”.

Ebben a vonatkozásban szemlélve a jutalékrendszert, a következők jelenthetők ki:

- Az a szemlélet, hogy az informatika nemcsak a megoldások szállítója, hanem az üzlet része, a biztosító ügyfélkörének, termékválasztékának és értékesítési csatornáinak komplexitásával egyenesen arányos.

- A fenti kijelentéshez vezető első lépés, hogy egy jól skálázott jutalékrendszer olcsóbb és ár-érték arányban vélhetően hasznos pilotja lehet egy adattárház projektnek.

- Nem tudható, hogy a közösségi alkalmazások növekvő használata pontosan milyen hatással lesz a biztosítóiparra, de különösen az alábbi tendenciákat tartjuk hasznosításra alkalmasnak: - Big Data elemzések, illetve ezek komplex hasznosíthatósága a marketingtől az adatvédelemig. Szegmentáció, különösen ennek az öntanuló alkalmazásai.

- Gamification - építve arra, hogy a biztosítási piacot az online tér felől közelítők inkább a fiatalabb korosztályokból kerülnek ki.

*Fülöp Attila, CPO, Swicon Zrt. (attila.fulop@swicon.hu, +36-1-883-9860)

Key words: insurance sales, digitization, commission system, gamification, sales support JEL: G22 


\section{SUMMARY}

The main objective of the study is to demonstrate how spreading of the multi-channel distribution model, the transformation of sales channels as an effect of digitization and younger generations' growing trust in the digital world reevaluate the tasks and challenges of Insurance IT.

Regarding the analysis of distribution channels in Europe, we have seen that the statistics in this respect are not at the appropriate level of stability. The series of data is fairly short, the data expressiveness is limited and the period under review was plagued by the 2008 crisis and constraints.

In our view the following statement - although data is not fully justified - still stands: During the test period of 2007-2012 distribution channels that were previously dominant and more reliable remained significant in major European member states. Even though data related to Europe has not confirmed the existence of a crisis-caused increased premium sensitivity, the case of the Hungarian MTPL serves as a strong argument for its existence. The example mentioned also demonstrates that online sales based on brokers' infrastructure can quickly decrease remaining profits and highlights the weaknesses of current measurements, too.

Regarding the analysis of regulatory challenges it was identified that the changes that came into force on January 1, 2015 could facilitate the purification of sales from misselling motivations, while becoming more customer-friendly. We think that in this context the primary task of the commission system is the support of moving process; on the other hand its modelling and planning capabilities are welcomeincluding the revenue planning of salespeople.

Based on our long-term experience in the US insurance industry generational changes are more striking in the US. So the phenomenon of generations entering the market having less and less distrust of the digital world is noticeable more easily.

It is impossible to know whether the extent of this transformation of distrust into trust is sufficient to be able to constitute the source of insurance relationships in mass - although the first step in the process, the achievement of credibility in service comparisons is already given.

In our opinion, insurers' IT managers are confronting a twofold challenge. On the one hand, they need to promote the traditional way of insurance processes, but on the other hand, they must keep pace with the evolution of information technology and with the expansion of digitization, since IT is no longer just a "supplier of solutions", but "part of the business".

From this perspective the following can be stated about the commission system:

- The approach, according to which IT is not just a supplier of solutions, but part of the business, is directly proportional to the insurance company's customer base, to the product range and to the complexity of its sales channels.
- A well-scaled commission system could be cheaper and possibly more useful first step to bigger data warehouse project.

- The precise effects of growing use of social applications in the insurance industry are not known, but we find the following trends particularly suitable for exploitation:

Big Data analysis and complex utilization from marketing to security

- Segmentation including self-learning applications

- Gamification - based on the fact that those approaching the online insurance market are typically from younger aged groups

\section{HIVATKOZÁSOK}

'A kgfb-biztositóváltások magyarországi elterjedtségében természetesen más tényezők is szerepet játszottak, ilyen például az egészen 2010-ig egységes január 1-jei évforduló.

2 2 agyarországon ilyennek tekinthetó például a Magyar Biztosítósok, Bankosok, Alkuszok és Pénzügyi Közvetítők címủ, mintegy 2.800 aktiv tagot számina racebook közôsségi oldaa

Például az internetes világba a tevékenységük, életkoruk stb. miatt aktívan bekapcsolódni nem tudók vagy egyszerúen az angol

A becslés egy iparági tanácsadó cégtőll, a PEND Consulting Kft.-tỏl származik. A becslés módszertana a következő volt: Első lépésMABISZ által közzétett adatait (életbiztositás folyamatos dija, életbiztositás egyszeri dija, kgfb, illetve egyéb nem-életbiztositátsok). Második lépésben ezek megoszlását becsülték meg értékesítési csatornák szerint társaságonként és termékccsatornánként. Harmadik lépésben a piac kevesebb mint 30\%-ot kitevơ maradéka került felosztásra már a felosztott dijak értékesitésis csatornák szerinti aggregált becslése szerint.

${ }^{5}$ A SWICON Magyarországon a jutalékrendszerek specialistájaként ismert. Az alábbiak az ügyfelekkel folytatott megbeszéléseken kristályosodtak ki, ami miatt ezúton is köszönetet szeretnék mondani. Másfelöl törekszünk arra is, hogy a jutalékrendszerekkel kapcsolatos - e cikkben is taglalt - követelményeket saját fejlesztéseinkkel szemben is érvényesítsük, igy tudjuk ügyfeleinket magas színvonalon kiszolgálni. 


\section{IRODALOMJEGYZÉK}

[1]: Biztositars.hu: Evrő̉l évre csökken a kgfb-t váltók száma (2015.01.22)

2 ]: CEA European Insurance in Figures Complete Data 2002, Basic Data 2003 (2004.06)

$142-1450$

http:///www.insuranceeurope.eu/uploads/Modules/Publications/1249034716_eif2004-2003-data.pd

[ 3 ]: CEA Statistics No39: Insurance Distribution Channels in Europe (2010.03) Distribution - Összefoglaló, 16 .

htp./Www. - Osuranceeurope.eu/uploads/Modules/Publications/cea-statistics-nr-39---distribution.pdf 2015.07.31.

[ 4 ]: CEA European Insurance In Figures -CEA Statistics No37 (2009.10) http://www.insuranceeurope.eu/uploads/Modules/Publications/eif-2009.pdf

[5]: CEA European Insurance In Figures -CEA Statistics No50 (2014.12)

http://www.insuranceeurope.eu/uploads/Modules/Publications/eif-2013-final.pd

[6]:Eurológus: Mégis megmaradnak a roaming dijak (2015.03.08) http://index

[ 7 ]: Felügyeleti kgfb idősor

http://www.mnb.hu/felugyelet/idosorok/iii-biztositasi-piaci-szervezetek/kotelezo-gepjarmu-felelossegbiztositas-idosorai-1

[ 8 ]: Gambone, Gregory: How to Sell Life Insurance Online? (Chron)

http://smallbusiness.chron.com/sell-life-insurance-online-12733.htm

9 ]:III. (Insurance Information Institute) - Buying Insurance: Evolving Distribution Channels 2014.10. help://www.

[ 10 ]: Intézményi honlapok/1 - Council for Disability Awareness

http://www.disabilitycanhappen.org/

[ 11 ]: Intézményi honlapok/2 - American Family Life Assurance Company (AFLAC)

http://www.aflac.com/

[ 12 ]: Intézményi honlapok/3 - Európai Unió /Szakpolitikák/Fogyasztóvédelem

http://europa.eu/pol/cons/index_hu.htm

[ 13 ]: Intézményi honlapok/4 - GEICO

https://www

[14]: Intézményi honlapok/5 - Allstate

https://www.allstate.com/
[ 15 ]: Intézményi honlapok/6 - Wikipedia.org / Generációk

(felosztás és X generáció

https://huwikikedia org/wiki/Z gener\%C3\%A Alcio C3\%B3 (Y generáció)

2015.07.31.

[ 16 ]: Intézményi honlapok/7 - Google dijösszehasonlító

https://www.google.co.uk/compare/carinsurance/form?p=hom

[ 17 ]: Intézményi honlapok/8 - Uniqa - Multipartner

http://www.uniqa.hu/home/01_Lakossagi/MultiPartner/

[ 18 ]: IMD1 - 2002/92 sz. EU direktíva

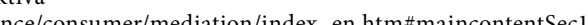

http://ec.europa.eu//finance/insurance/consumer/mediation/index_en.hth

2015.07.31.

[ 19]: Mason, Pinsent: The Insurance Distribution Directive: changes to the regulation of insurance intermediaries in the EU ges-to-the-regulation-of-insurance-intermediaries-in-the-eu/

[ 20 ]: MTI: Tovább duzzad Hillary Clinton e-mail-botránya (2015.03.06)

http://www.atv.hu/kulfold/20150306-tovabb-duzzad-hillary-clinton-e-mail-botrany

21 ]: Portfolio.hu: Diszkrimináliák a nőket a biztosítók decembertől (2012.10.04) http://www.

[ 22 ]: Portfolio.hu: Erre készülnek idén a biztositók (körkérdés és válaszok - 2015.02.05) http://www.portfolio.hu/users/elofizetes_info.php?t=cikk\&i=209786

2015.07.31.

[ 23 ]: PSZÁF-közlemény az életbiztositási termékek ,jutalékpiramis" rendszerben történő értékesitéséről egyes állásfoglalásaiban (2011. április 28.),

作://www.mnb.hu/archivum/Felugyelet/root/fooldal/intezmenyeknek/biztositok/hirek/jutalekpiramis_110428

[ 24 ]: PSZÁF: Második Fogyasztóvédelmi Kockázati Jelentés 2012 (37 oldal)

http://alk.mnb.hu/data/cms2378897/FV_kockazati_jelentes121217.pdf

[25]: Sigma 06/2013 - Life insurance / Focusing on the comsumer, 20 oldal 11 f́bra. http://www.biztositasiszemle.hu/files/201312/sigma6_2013_en.pdf

[ 26 ]: Treaster, Joseph B.: Internet Sales Offer an Insurance Alternative (NYTimes, 1996. 09.06)

http://www.nytimes.com/1996/09/06/business/internet-sales-offer-an-insurance-alternative.html 2015.07.31.

[27]:Világgazdaság Online: Hatmilliárdert eladták a Netrisk.hu többséget (2010.07.01) 作://www.vg.hu/penzugy/biztositas/hatmilliardert-eladtak-a-netriskhu-tobbseget-320042

[28]: Will, Reiner, Dr. ügyvezetö (Assekurata Assekuranz Ratimg Gmbh), interjú (Assekurata Punkt! 2013/45) http://www.assekurata.de/uploads/tx_news/Assekurata_Newsletter_45.pdf 